Review

\title{
Therapeutic Evaluation of microRNAs by Molecular Imaging
}

\author{
Thillai V. Sekar1, Ramkumar Kunga Mohanram¹,2, Kira Foygel1, and Ramasamy Paulmurugan ${ }^{凶}$ \\ 1. Molecular Imaging Program at Stanford, Bio-X Program, Department of Radiology, Stanford University School of Medicine, Stanford, California, \\ USA. \\ 2. Current address: SRM Research Institute, SRM University, Kattankulathur- 603 203, Tamilnadu, India
}

$\triangle$ Corresponding author: Ramasamy Paulmurugan, Ph.D. Department of Radiology, Stanford University School of Medicine, 1501, South California Avenue, \#2217, Palo Alto, CA 94304. Phone: 650-725-6097; Fax: 650-721-6921. Email: paulmur8@stanford.edu

(C) Ivyspring International Publisher. This is an open-access article distributed under the terms of the Creative Commons License (http://creativecommons.org/ licenses/by-nc-nd/3.0/). Reproduction is permitted for personal, noncommercial use, provided that the article is in whole, unmodified, and properly cited.

Received: 2013.07.26; Accepted: 2013.09.22; Published: 2013.12.06

\begin{abstract}
MicroRNAs (miRNAs) function as regulatory molecules of gene expression with multifaceted activities that exhibit direct or indirect oncogenic properties, which promote cell proliferation, differentiation, and the development of different types of cancers. Because of their extensive functional involvement in many cellular processes, under both normal and pathological conditions such as various cancers, this class of molecules holds particular interest for cancer research. MiRNAs possess the ability to act as tumor suppressors or oncogenes by regulating the expression of different apoptotic proteins, kinases, oncogenes, and other molecular mechanisms that can cause the onset of tumor development. In contrast to current cancer medicines, miRNA-based therapies function by subtle repression of gene expression on a large number of oncogenic factors, and therefore are anticipated to be highly efficacious. Given their unique mechanism of action, miRNAs are likely to yield a new class of targeted therapeutics for a variety of cancers. More than thousand miRNAs have been identified to date, and their molecular mechanisms and functions are well studied. Furthermore, they are established as compelling therapeutic targets in a variety of cellular complications. However, the notion of using them as therapeutic tool was proposed only recently, given that modern imaging methods are just beginning to be deployed for miRNA research. In this review, we present a summary of various molecular imaging methods, which are instrumental in revealing the therapeutic potential of miRNAs, especially in various cancers. Imaging methods have recently been developed for monitoring the expression levels of miRNAs and their target genes by fluorescence-, bioluminescence- and chemiluminescence-based imaging techniques. Mature miRNAs bind to the untranslated regions (UTRs) of the target mRNAs and regulate target genes expressions. This concept has been used for the development of fluorescent reporter-based imaging strategies to monitor the functional status of endogenous miRNAs, or the respective miRNAs transiently co-expressed in cells. Bioluminescence-based imaging strategies have been used to investigate various stages of miRNA processing and its involvement in different cellular processes. Similarly, chemiluminsecence methods were developed for in vitro miRNA imaging such as monitoring their therapeutic roles in various cancer cell lines.
\end{abstract}

Key words: miRNAs, molecular Imaging

\section{Introduction}

\section{MicroRNAs}

MicroRNAs (miRNA) are single stranded, evolutionarily conserved non-coding RNAs of 19 to 25 nucleotides in length spliced from hair-pin loop transcripts of pre-miRNAs, which are $\sim 60$ to 80 nucleotides in length. MicroRNAs are coded by approximately $1 \%$ genome in many species $[1,2]$, and by approximately $3 \%$ in the human genome. MicroRNAs 
function as regulatory molecules of gene expression in cells. MicroRNAs have been shown to regulate the expression of a variety of target genes that are involved in different cellular processes, which include cell proliferation, apoptosis, differentiation, stem cell development, and genes that are associated with various human diseases, including cancer [3]. MiRNA coding genes are transcribed into long primary transcripts called pri-miRNA by RNA polymerase II, with local hairpin structures and flanking sequences. Drosha and RNase III are two other nucleases which trim the flanking sequence and produce the precursor miRNA known as pre-miRNA [4]. This entire process of pre-miRNA processing occurs inside the nucleus (Figure 1). Subsequently, the pre-miRNA is actively transported to cytoplasm through nuclear pore complex by exportin-5, one of the nuclear transport receptors [5]. Following the export, pre-miRNA is cleaved by Dicer, the cytoplasmic RNase III [6], into mature miRNA of $\sim 22$-bp duplex, and thereafter, effector complexes that are termed as 'miRNP' (miRNA-containing ribonucleoprotein complex) or 'miRISC' (miRNA-containing RNA-induced silencing complex) are formed. The 22-bp duplex is not stable in the effector complex; one strand of the duplex, possibly the one with unstable base pairs at the $5^{\prime}$-end, remains active and directs the RISC complex to target mRNA and provides the regulatory silencing effects by messenger degradation or blocking translation initiation [7]. The miRNA encoding gene sequences are mostly located in the intergenic regions. However, some of the miRNA genes are also identified from the intronic regions of some well-known genes in both the sense and antisense orientations [8]. MiRNAs are encoded either independently, or as a cluster of several miRNAs under the same promoter [9].

\section{Functional roles of miRNAs in normal cells, and cells in different pathological conditions}

MicroRNAs of different types are expressed by cells to maintain cellular homeostasis. By contrast, dysregulated expressions of various miRNAs are found in cells at different pathological conditions. It is well known that microRNAs are implicated in various human diseases. According to miRbase [18], 1,921 mature miRNAs were identified in human cells. So far, 349 miRNAs have been identified to be associated with over 163 different human diseases [10], with most of them being associated with various cancers. In cancer cells, dysregulated miRNAs are mainly involved in regulating cell differentiation, proliferation, and apoptosis. Apart from cancer, microRNAs are also reported to be associated with cardiovascular diseases [11], neurological diseases [12], viral diseases [13], and metabolic disorders [14].

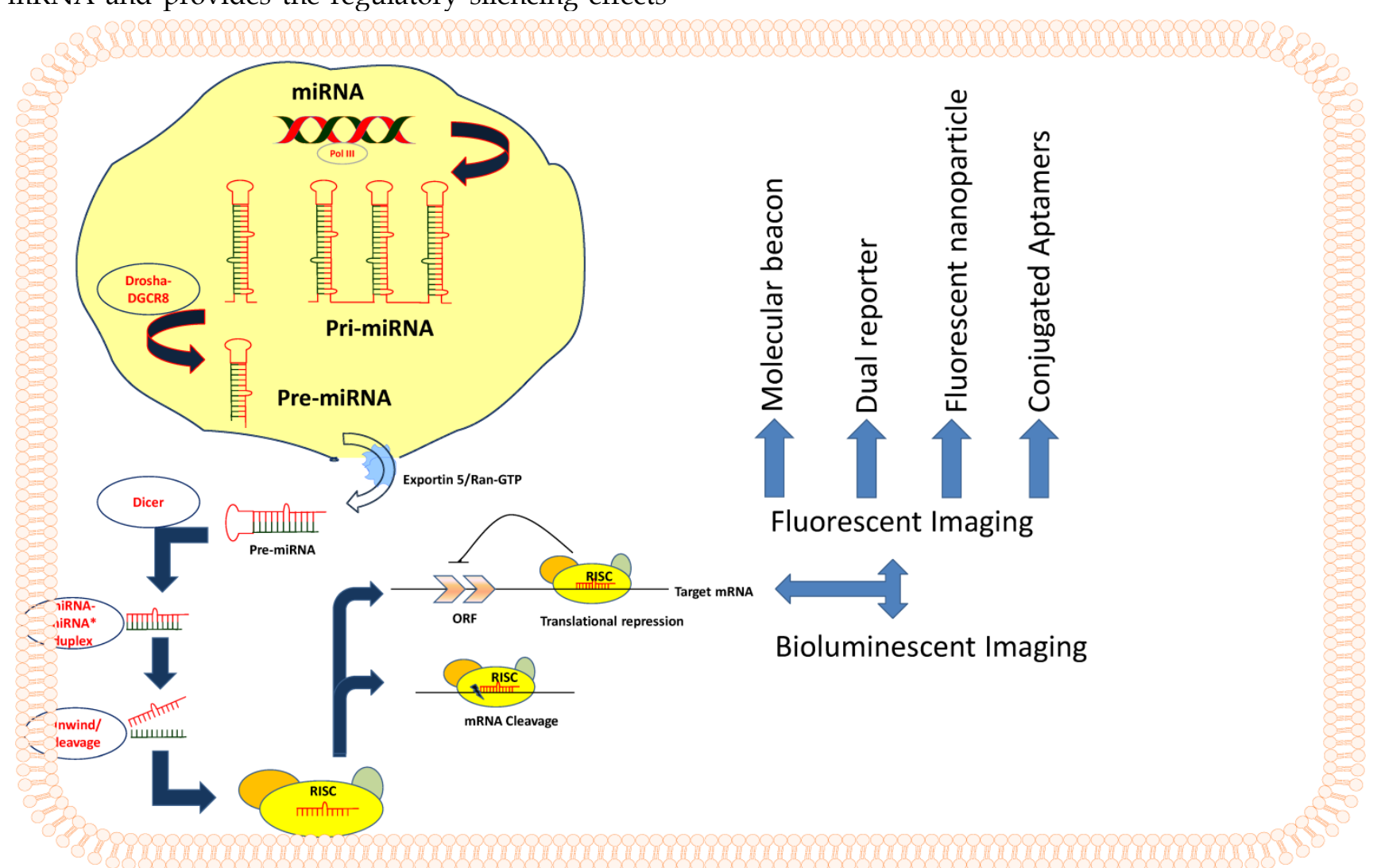

Figure I. Schematic representation of miRNA processing and various modes of Imaging. 


\section{MicroRNAs in cancer}

Despite the substantial progress in understanding the complex signaling network in cancer, effective therapies remain scarce due to unpredictable disruption of oncogenic pathways, drug resistance, and drug-induced toxicity. Because cancer is a complex disease that lacks effective therapy, there is an urgent need for researchers and clinicians to combine drugs targeting more than one pathway and develop novel therapeutic strategies. The discovery of microRNAs provides new hope for accomplishing this task with the promising success rate. Supported by solid evidence for their critical role in cancer and bolstered by a unique mechanism of action, miRNAs are likely to yield a new class of targeted therapeutics. In contrast to current cancer medicines, miRNA-based therapies function by subtle repression of gene expression on a large number of oncogenic factors, and therefore are anticipated to be highly efficacious. After completion of target validation for several candidates, the development of therapeutic miRNAs is now moving to a new stage that involves pharmacological drug delivery, preclinical toxicology, and regulatory guidelines, using powerful molecular imaging techniques that can monitor processes inside the cell and study their complex pathways.

Single miRNA can control multiple oncogenes and regulate oncogene-related cellular pathways that lead to the development of cancer. Because, cancer is such a heterogeneous disease, it cannot be successfully treated by targeting a single gene of interest [15, 16]. The promising ability of miRNAs to control several genes associated with a particular cellular pathway therefore may hold the key to therapeutic success. Based on regulatory mechanisms in which miRNAs are involved in cancer, they can be categorized either as oncogenic or tumor suppressors.

MicroRNAs were documented to have multifaceted activities that possess direct or indirect oncogenic properties that can promote cell proliferation, differentiation, and development of many types of cancer. So far, numerous microRNAs have been reported to play an oncogenic role by inhibiting tumor suppressor genes, and by controlling the genes which regulate cell cycle progression. MicroRNAs have also been reported to mediate metastasis by controlling genes that are responsible for epithelial-mesenchymal transition and cell invasion. For example, microRNA-155 was identified as oncogenic microRNA capable of inducing lymphoblastic leukemia and also found to be over-expressed in solid tumors such as breast, colon, and lung cancer [17]. MicroRNA 17-92 cluster was shown to be over-expressed in human B-cell lymphoma by promoting c-myc mediated oncogene- sis [18]. MiR-21 has been implicated in the development of glioblastoma, and it is also recognized as an anti-apoptotic miRNA due to its ability in blocking genes responsible for controlling apoptosis [19].

\section{Tumor suppressor miRNAs}

MicroRNAs possess the ability to act as tumor suppressors by regulating the expression of oncogenes, apoptotic proteins, kinases, and other molecular mechanisms that can cause the onset of tumor development. MicroRNA let-7 was identified as a tumor suppressor in different types of tumors, such as breast cancer [20], colorectal cancer [21], lung cancer [22], and leiomyoma [23]. MiR-122 from let-7 family, and $\mathrm{miR}-101$, are shown to function as tumor-suppressors in hepatocellular carcinoma (HCC) [24]. Recently, miR-409-3p was recognized as a tumor suppressor by targeting transcriptional regulator PHF10 in gastric cancer [25]. MiR-508-3p and miR-509-3p were reported as tumor suppressors in renal cell carcinoma (RCC) mainly because their overexpression has been shown to significantly suppress the proliferation of RCC, induce cellular apoptosis, and inhibit tumor cell migrations in vitro [26]. Similarly, miR-1, miR-206 and miR-29 were shown to play a role of tumor suppression in rhabdomyosarcoma [27]. Downregulation of these miRNAs stabilizes the expression of PAX3 and CCND2 in embryonal and alveolar rhabdomyosarcoma types [27]. E26 transformation-specific sequence (ETS)-2, a transcriptional modulator, suppressed the expression of miR-196b during gastric cancer development, and the association of ETS2 and miR-196b were shown to have a deterministic role in the development of cancer. In addition, miR-196b is suggested to possess a tumor suppressor property [28]. MiR-203 was recognized as a tumor suppressor in human melanoma cells, as it caused the reduction of E2F3a, E2F3b, and ZBP-89 proteins levels, which are otherwise shown to be highly expressed in human malignant melanoma, Mewo, cells [29].

Numerous lines of evidence have supported the idea that microRNAs act as tumor suppressors by regulating anti-apoptotic proteins. MicroRNA-122, a liver-specific miRNA that is associated with the pathogenesis of HCC, was found to be downregulated, and is reported to be responsible for HCC resistance to conventional chemotherapy. Overexpression of miR-122 in HCC cells made them sensitive to adriamycin (ADM) or vincristine (VCR) by downregulating MDR-related genes (MDR-1, GST-ח, MRP), anti-apoptotic gene (Bcl-w), and cell cycle related gene (cyclin B1), thereby acting as a tumor suppressor [30]. Expression of miR-15 and miR-16 was found to be indirectly proportional to that of anti-apoptotic B-cell lymphoma 2 protein (Bcl2) in chronic lymphocytic 
leukemia (CLL). Also, Bcl2 repression by miR-15 and miR-16 could induce apoptosis [31]. Lam et al., have identified 19 different miRNAs which can induce HCT-111 cells sensitive to ABT-263 (navitoclax), a Bcl2 family inhibitor. Of these 19 miRNAs, 15 were identified to sensitize CHL1 melanoma cells to ABT-263. Out of 12 miRNAs that reduced MCL1 protein expression, 10 were found to have direct interaction with 3'-UTR region of MCL1 gene [32].

Ectopic expression of miRNA-199a and miRNA-199a* induced apoptosis in many cancer cells through caspase-dependent and caspase-independent pathways, respectively. Luciferase reporter-based analysis identified MET proto-oncogene as a target of miR-199a*, whereas extracellular signal-regulated kinase 2 (ERK2) was also downregulated by miR-199a* [33]. Kefas et al., reported miR-7 as a tumor suppressor through suppression of epidermal growth factor receptor (EGFR); it independently inhibited Akt pathway by targeting its upstream regulators Ras 1 or Ras 2 [34].

\section{Oncogenic role of Specific MicroRNAs in various Cancers \\ Prostate cancer}

Research reports have revealed that microRNA expression becomes altered with the development and progression of prostate cancer. Some of these microRNAs include miR-106a $\sim 363$ clusters and miR-106b 25 clusters targeting E2F1; regulate the expression of cancer-related genes in prostate cancer cells [35]. MiR-21 could promote cells' resistance to apoptosis, motility, and invasion by targeting MARKS, ANP32A, and SACA4 [36]. The presence of an auto-regulatory feedback loop between E2F factors and miR-17/92 has been shown to promote prostate cancer [37]. On other hand, miR-17/92 acts as a therapeutic agent by suppressing tumorigenicity of prostate cancer through inhibition of mitochondrial antioxidant enzymes MnSOD, GPX2, and TRXR2 [38].

It is interesting to note that therapeutic delivery of antisense microRNA (antagomiR) to miR-10b did not inhibit growth of the existing metastatic lesions, but rather its inhibition can be used to prevent further metastatic spread from the existing primary tumors [39]. By contrast, Takeshita et al. have reported that miR-16 can block the growth of disseminated prostate cancer cells, and might therefore prove to be a useful target in treating metastatic disease [40]. Thus, miR-10b and miR-16 illustrate the diversity of miRNAs' functions in cancer, and show how miRNAs can create unique opportunities for therapeutic intervention in cancer. The combination of miR-10b antagonist and miR-16 mimic may prove particularly effective in treating prostate cancer patients.

\section{Liver cancer}

Hepatocellular carcinoma (HCC) is the major primary liver cancer, and the fifth most common cancer worldwide [41], with about 750,000 new cases reported each year (International Agency for Research on Cancer, IARC, 2008). The annual mortality of about 700,000 was reported globally [42]. An estimated $80-90 \%$ of all HCC arise from cirrhotic liver. Low survival is attributed to late diagnosis, resistance to treatment, tumor recurrence, and metastasis, hence stressing the need for novel early diagnostics and therapeutics. The findings that individual microRNAs may target several hundred genes, and that a large percentage of mRNAs may be subject to regulation by microRNAs, further underscore the emerging importance of microRNA-mediated regulation in HCC $[43,44]$.

A recent work by Hatziapostolou and colleagues has defined a new player in hepatocellular carcinogenesis that can serve as a potential target for the treatment of HCC [45]. An inflammatory feedback loop circuit involving miR-24/miR-629/HNF4alpha/miR-124/STAT3/IL-6 $\mathrm{R}$ has been identified, which upon activation can suppress HNF4-alpha, thereby inducing liver cancer. Considering therapeutic success and efficacy of miR-124, Hatziapostolou et al., further proposed its use in treatment of liver cancer [45]. Their results suggest the potential of using miR-124 therapy in the advanced stages of HCC.

\section{Lung cancer}

Several recent studies have clearly highlighted the roles of miRNAs in lung carcinogenesis [46-48]. Muller et al., have shown the difference in the expression profiles of miRNAs in lung cancer as compared to normal lung tissues, although the significance of the aberrant expression of different miRNAs is poorly understood [46]. Among the reported miRNAs that are downregulated in lung cancer, the miRNA-29 family $(29 a, 29 b$, and 29c) has intriguing complementarities to the 3'-UTRs of DNA methyltransferases-3A (DNMT-3A) and DNMT-3B (de novo methyltransferases), the two key enzymes that are frequently upregulated in lung cancer, involved in DNA methylation, and associated with poor prognosis. These studies also demonstrated that the expression of miR-29s $(a, b$, and $c)$ were inversely correlated with the expression of DNMT3A and $-3 \mathrm{~B}$ in lung cancer tissues. DNMT3A and -3B have been clearly implicated as direct targets for miR-29 [49]. The expression of miR-29s ( $a, b$ and $c)$ in lung cancer cell 
lines restored normal patterns of DNA methylation, inducing re-expression of tumor suppressor genes such as FHIT and WWOX that were previously silenced by methylation, thereby inhibiting tumorigenicity in vitro and in vivo [46]. These findings support the role of miR-29s in epigenetic normalization of non-small cell lung cancer (NSCLC), providing a rationale for the development of miRNA-based therapeutic interventions for the treatment of lung cancer.

An intricate and finely tuned circuit involving c-myc, miR-17/92, and HIF1 $\alpha$ is responsible for causing lung cancer. MiR-221 and miR-222, by targeting PTEN and TIMP3 tumor suppressors, respectively, induce TRAIL resistance and enhance cellular migration. MiR-221/222 modulates both epidermal growth factor (EGF) and MET receptors by targeting APAF1. It is also found to be responsible for gefitinib resistance and promoting metastasis in NSCLC. Axl receptor was found to be regulated by miR-34a and miR-199a/b, and suppressed by promoter methylation in solid lung cancers [47]. Overexpression of miR-15/16 is reported to induce cell cycle arrest in $\mathrm{G}(1)-\mathrm{G}(0)$, which targets CCND1, CCND2, and CCNE1, thereby suppressing the metastatic properties of tumors. MiR-200 was found to suppress lung adenocarcinoma metastasis by targeting Flt1/vegfR1 expression in tumor cells [48].

\section{Colon and rectal cancer}

MicroRNAs are reported to be abnormally dysregulated in colon cancer tissues. Artificial dysregulation of certain microRNAs triggers tumorigenesis or apoptosis, depending on which microRNA is being manipulated. Although the natural mechanisms for the dysregulation of microRNAs are still largely unknown, one theory tested in colon cancer suggests that DNA hypermethylation could be the possible main cause for the downregulation of certain microRNAs. Specific microRNA expression patterns help characterize a particular type of cancer, and may be used as a prognostic factor in determining responses to therapy [50].

Yaguang et al. analyzed 10 different miRNAs (hsa-let-7b, hsa-let-7g, hsa-miR-15b, hsa-miR-181b, hsa-miR-191, hsa-miR-200c, hsa-miR-26a, hsa-miR-27a, hsa-miR-30a-5p, and hsa-miR-30c) for their potential prognostic value in colorectal cancer patients. Some of these miRNAs function as oncogenes due to the fact that their over-expression can cause cancers. Hsa-miR-200c has been found to be a potential novel prognostic factor in colorectal cancer [51]. MiR-16 has been shown to play the central role of post-transcriptional regulator of COX-2, and was implicated in the development of colorectal cancer. Inactivation of mismatch repair is induced by miR-155 targeting hMSH2, hMSH6, and hMLH1 [52]. MiR-34 mediates repression of SIRT1 and leads to apoptosis only in colon cancer cells that express wild-type p53. A new link among p53, miR-34, and Snail1 in the regulation of cancer cells, EMT property was studied earlier to analyze the effect of miR-34 on metastasis. MiR-17-92 cluster was found to be upregulated in colonocytes. MiR-17-92 targets TSP-1 and CTGF were co-expressed with impaired K-Ras, c-Myc, and p53 activities in colon cancer [38].

\section{Lymphoma and Leukemia}

MiRNAs play a significant role in the prognosis of lymphoma and leukemia with impressive accuracy. George et al. showed that miR-15 and miR-16 are located on chromosome 13q14, a region frequently deleted in more than half of B-cell chronic lymphocytic leukemias (B-CLL). Detailed deletion and expression analysis revealed that miR-15 and miR-16 genes are located within a 30-kb region which is frequently lost in CLL, and that both are deleted or downregulated in majority $(\approx 68 \%)$ of CLL cases [53]. Charles et al. investigated the expression of MIRN155 (miR-155) and MIRN21 (miR-21), both of which were found to be highly expressed in Diffuse Large B-Cell Lymphoma (DLBCL) [54], as well as, upregulation of MIRN210 (miR-210) was found to be associated with more general malignant phenotypes [55].

Cell dissemination and aggressiveness are phenotypic traits of DLBCL, which typically express high levels of miR-155 and lack human germinal center-associated lymphoma (HGAL) protein expression. In addition, miR-155 highlighted a hitherto unappreciated role of SA5 in lymphoma biology and defined a unique mechanism used by cancer cells to escape TGF- $\beta$ 's growth-inhibitory effects. Bic/miR-155 plays a key role in the homeostasis and function of the immune system in lymphocytes targeting C-MAF [56]. Functional genomics approach revealed a coordinated clamp-down on several regulators of phosphatidylinositol-3-OH kinase-related survival signals by leukemogenic miR-19 targeting BIM, PTEN, PRKAA1, and PPP2R5e in acute T-cell lymphoblastic leukemia [57]. MiR-9-mediated downregulation of PRDM1/Blimp-1 contributes to phenotype maintenance and pathogenesis of lymphoma cells by interfering with normal B-cell terminal differentiation [58]. Distinct miR-15/16 profiles are associated with an increased proliferative capacity and a 'late' germinal center B-cell phenotype characterized by follicular lymphoma [59].

\section{Pancreatic cancer}

Pancreatic ductal adenocarcinoma (PDAC) is one of the aggressive cancer types with a median survival 
of less than 6 months and not amenable to conventional chemotherapeutic agents. Various miRNAs have been associated with the development of PDAC. Among these, miR-216 is down regulated consistently in PDAC when compared to normal pancreatic tissue [60]. Eight microRNAs, namely miR-196a, miR-190, miR-186, miR-221, miR-222, miR-200b, miR-15b, and miR-95, were identified to be overexpressed in a study in which pancreatic cancer tissue samples and cell lines were analyzed by differential expression profiles for 95 miRNAs by real time PCR. The upregulation of most of these miRNAs ranged from 3.3 to 79 folds in pancreatic cancer tissue samples and cell lines (Panc-1, MIA PaCa-2, BxPC-3, Hs766T, ASPC-1, CaPan-1, CaPan-2, Panc3.27, HPAF-II, and PL45) when compared to human pancreatic ductal epithelial (HPDE) cells [61].

\section{Glioma}

Glioma is a highly fatal malignant disease as well as the most common among neural malignancies, and its unique invasiveness renders it highly resistant to therapies [62]. This invasive phenotype could be controlled in part by altering some specific miRNAs. It is obvious from various investigations that miRNAs play a crucial role in glioblastoma pathogenesis. A strong positive correlation between miR-21 expression and pathological grade in glioma tissues has been documented. Chan et al. demonstrated that knockdown of miR-21 in cultured glioblastoma cell lines triggered caspase activation that resulted in apoptotic cell death, suggesting an anti-apoptotic function of miR-21 [19]. MiR-21 expression was found to be regulated by $\beta$-catenin/STAT3 pathway and to promote glioma cell Invasion by directly targeting RECK [63]. Moreover, other direct targets of miR-21 are p63 (a homolog of p53), p53 activators JMY, TOPORS, TP53BP2, DAXX, and HNRNPK which stabilize p53 protein levels by interfering with MDM2 and acting as p53 transcriptional cofactor, as well as assisting p53 in transactivating genes that induce apoptosis and cell growth arrest [64]. MiR-221 is overexpressed in glioblastoma tissue samples and also in many glioblastoma cell lines [65]. Sage et al. reported that glioblastoma cell lines require higher expression of miR-221/222 for maintaining low p27Kip1 levels and continuous proliferation [66]. High levels of miR-221/222 expression correlate with low levels of p27Kip1 in glioblastoma. In addition, miR-27a has been shown to be abundantly expressed in glioma tissues and the inhibition of miR-27a significantly suppresses the proliferation and invasiveness of U87 glioma cells [67]. Shi et al. reported downregulation of miR-181a and miR-181b in both human gliomas and glioma cell lines [68]. The expression level of
miR-181a was negatively correlated with tumor grading, whereas miR-181b showed significant differences in expression only between high grade (WHO III and IV) and low grade gliomas.

MiR-7 is another potential tumor suppressor in glioblastoma targeting critical cancer signaling pathways. It has been documented that miR-7 directly regulates cell invasion by targeting FAK in glioblastoma [69]. Recently, Sun et al. reported that MiR-34a suppresses cell proliferation and induces apoptosis in U87 glioma stem cells [70]. MiR-128 expression significantly reduced glioma cell proliferation in vitro and glioma xenograft growth in vivo [71]. It has been demonstrated that miR-128 directly targets a transcription factor E2F3 $\alpha$ which activates genes mainly involved in cell cycle progression. MiR-128 can also inhibit proliferation of brain cells by negative regulation of E2F3 $\alpha$ [72]. Another direct target of miR-128 is an oncogene Bmi- 1 , which regulates tumor suppressors like p53 and p16Ink4a [71]. The overexpression of miR-181d was reported to suppress the proliferation and trigger cell cycle arrest and apoptosis in glioma cell lines. K-ras and Bcl-2 were identified as direct targets of miR-181d, and were found to be upregulated in glioma samples [73]. Moreover, the xenograft tumors of U251 cells treated with miR-181d suppressed tumor growth in vivo.

\section{Renal cancer}

Renal cell carcinoma (RCC) is a heterogeneous disease with widely varying prognosis [74]. It develops in the tubules of the kidney, the main part of the kidneys filtering system. The expression levels of different miRs were significantly ameliorated in RCC cell lines and in tissue specimens. Ectopic restoration of miRs in RCC has promised a significant inhibition of cell proliferation and invasion, and moreover, revealed induction of apoptosis and cell cycle arrest. Juan et al., [75] reported a panel of 10 miRNAs (miR-200c, miR-185, miR-34a, miR-142-3p, miR-21, miR-155, miR-224, miR-210, and miR-592), the expression of which could distinguish RCC from normal kidney cells. In particular, miR-21 was found to be upregulated in many cancers, was also upregulated in RCC. Moreover, miR-34a was more specifically upregulated in RCC. MiR-141 and miR-200c were reported to be the most downregulated miRNAs in RCC, and were found to target ZEB2, a transcriptional repressor from the EMT pathway [76]. The oncogenic miR-185 has been reported to be significantly upregulated in RCC and negatively correlated with the tumor suppressor gene PTEN [77]. Dromard et al. [78] identified two more targets of miR-185, which include PTPN13, a Fas-associated protein tyrosine phosphatase and a putative tumor suppressor gene that can 
inhibit PI3K/AKT signaling, suppress the influence of insulin-like growth factor-I on cell survival, and induce apoptosis, and suppress KCNJ16, a member of the potassium channel subfamily of membrane proteins [79].

It has been reported that miR-26a target PTEN, and may therefore block its translation leading to downstream signaling effects that could result in the initiation of protein translation, mediated through mTOR signaling pathway. In addition, miR-26a overexpression targets histone methyltransferase, an enhancer of Zeste homolog 2 (Ezh2), thereby promoting cellular differentiation [80]. Expression of miR-16, located on chromosome 13q14, can interfere with either oncogenic or tumor suppressor pathways [53]. Bcl-2 protein has been reported as one of the miR-16 target genes. Transfection of anti-miR-16 suppresses miR-16 function, can upregulate the Bcl-2 expression and induce apoptosis in cancer cells [81]. MiR-16 can also regulate two other targets, such as HMGA1 and caprin-1, which are involved in cell proliferation [82].

\section{Breast cancer}

Breast cancer is the most common malignant tumor in women, accounting for $31 \%$ of all female cancers worldwide [83, 84]. The major reason for therapeutic failure is the development of resistance against current therapeutic agents. It is increasingly evident that drug resistance develops in mammary carcinoma cells after prolonged exposure to the antineoplastic agents [85]. It is also likely that resistant cells present in the tumor before treatment evade therapy and facilitate relapse.

Drug-resistant tumors are best described by their ability to undergo epithelial to mesenchymal transition (EMT) and enrichment of tumor-initiating cells (TIC). This results in highly aggressive tumors, usually after a period of dormancy. Recent studies have strongly demonstrated that miRNAs could regulate both EMT [86] and formation of cancer-initiating cells [87]. Considering the ubiquitous role of miRNAs in regulating numerous cellular pathways, it is highly possible that they can play key roles in EMT transition as well as contribute for the development of resistance. Sarmila et al., reported that tamoxifen-resistant and tamoxifen-sensitive derivatives of human breast adenocarcinoma cell lines (MCF7) showed increased expression of miR-221, miR-222, and miR-181b, and downregulation of miR-21, miR-342, and miR-489 in the tamoxifen-resistant cells [88]. Expression of miR-221, miR-222, and miR-181b was also significantly elevated in the HER2/neu-positive primary human breast cancer that is known to exhibit relatively high level of resistance to endocrine therapy [89]. The level of cell cycle inhibitor p27 (Kip1), one of the targets of miR-221/222, was significantly decreased in tamoxifen-resistant cells. MiR-24, miR-27, miR-23, and miR-200 were also downregulated in the tamoxifen-resistant cells. Similarly, other results suggest increased expression of miR-375, miR-171, miR-213, miR-203, and miR-32 in drug-resistant breast cancer cells [89].

Notably, suppression of miR-21 can inhibit tumor growth by targeting tumor suppressor tropomyosin 1 (TPM1) protein. In addition, the tumor suppressor protein programmed cell death 4 (PDCD4) gene is also regulated by miR-21, and it has been demonstrated that PDCD4 is a functionally important target for miR-21 in breast cancer cells [90]. It has been reported that TWIST, the transcription factor that induces the expression of a specific microRNA (miR-10a/10b) which suppresses its direct target and in turn activates another pro-metastatic gene, can promote tumor cell invasion and metastasis by targeting HOXD10 [91]. MiR-221/222 promotes EMT by acting on TRSP1 and contribute to more aggressive clinical behavior of basal-like breast cancers [38]. Dicer, the miRNA processing protein, is low in ER $\alpha$-negative breast cancers, because such cells express high miR-221/222 and Dicer inhibition by miR-107/103 steers epithelial cancer toward a less-differentiated, mesenchymal fate to foster metastasis. The miR-17/92 cluster plays an important role in breast cancer cell invasion and migration by suppressing HBP1 and subsequently by activating Wnt/ $\beta$-catenin. MiR-155 is an oncomiR in breast cancer targeting SOCS1, and it has been suggested that miR-155 may serve as a bridge between inflammation and cancer [92].

In some cases, miRs contribute actively to suppress the cancer cell proliferation, acting as therapeutic agents. For instance, MiR-31 employs multiple mechanisms to oppose metastasis by targeting ITGA5, RDX, RhoA, FZD3, M-RIP, MMP16, therefore fighting the metastatic behavior of breast cancer cells [93]. Downregulation of the miR-200 family may be an important step in tumor progression, whereby miR-200 family targets ZEB1 and ZEB2 that have suppression effect on metastasis [94]. MiR-200c plays a tumor suppressor role by negatively regulating EGF-driven cell invasion, viability, and cell cycle progression in breast cancer by targeting PLC1. MiR-200c sensitizes cells to apoptosis mediated by CD95 that targets FAP1, whereas miR-200c actively represses a program of mesenchymal and neuronal genes involved in cell motility and anoikis resistance by acting on a set of genes, including FN1, LEPR, NTRK2, and ARHGAP19 $[95,96]$. 
MicroRNAs such as miR-9 [97], miR-200a, miR-200b [98], miR-200c [99], miR-141, miR-429 and miR-205 [100] are associated with the metastasis of breast cancer. MicroRNAs govern the metastasis of breast cancer by regulating proteins which maintain cellular homeostasis. E-cadherin, transforming growth factor $\beta$ (TGF- $\beta$ ), HER3, vimentin, amphiregulin, and Akt are some of the proteins affected either directly or indirectly by miRNAs, through which metastasis of breast cancer is regulated.

Comprehensive microarray analysis by Iorio et al. in 76 breast tumors and 34 normal breast specimens has identified 29 miRNAs which are dysregulated in breast cancer [101]. Also, the expression of miR-30 was shown to be correlated with estrogen receptor and progesterone receptor status; expression of miR-213 and miR-203 was correlated with tumor stage. The differential expression of several let-7 isoforms was associated with features such as progesterone receptor status, lymph node metastasis, and high proliferation index in breast tumor samples. A study by Mattie et al. has also identified very specific sets of miRNAs associated with breast cancers that were defined by their Her2neu/ErbB2 status or their ER and progesterone receptors status [102]. With respect to differential miRNA expression, especially in relation to progesterone receptor status, miR-155 was shown to be expressed at much higher levels in PR-positive tumors, as shown by blood plasma analysis [103]..

The search for general regulators of breast cancer metastasis has identified a set of miRNAs whose expression is specifically lost as human breast cancer cells develop metastatic potential. Using human breast cancer cells in vivo, Tavazoie et al. have shown that restoring the expression of such miRNAs in malignant cells suppresses lung and bone metastasis [104]. Similarly, restoration of miR-126 reduces overall tumor growth and proliferation, whereas miR-335 was shown to reduce metastatic cell invasion. Given that expression of mIR-126 and miR-335 is lost in a majority of primary breast tumors from the relapsing patients and the loss of expression of either miRNA is associated with poor metastasis-free survival, and authors have therefore identified these two mRNAs as metastasis suppressors in human breast cancer. Another study by Foekens et al. have identified four miRNAs associated with aggressiveness of lymph node-negative, estrogen receptor positive human breast cancer [105].

Another interesting work by Zhao and co-workers implicates specific miRNAs' role in negative regulation of estrogen receptor $\alpha$, especially elevated in ERa-negative cells [106]. MiR-221 and miR-222 were shown to directly interact with the 3'-untranslated region of ERa mRNA. Ectopic expression of miR-221 and miR-222 in ERa-positive MCF-7 and T47D cells resulted a decrease in ERa protein level but not its mRNA levels, whereas knockdown of miR-221 and miR-222 partially restored ERa in ERa-protein negative/mRNA-positive cells. What is important in this observation is that miR-221- and/or miR-222-transfected MCF-7 and T47D cells became resistant to tamoxifen compared to vector-treated cells. Furthermore, knockdown of miR-221 and/or miR-222 sensitized MDA-MB-468 cells to tamoxifen-induced cell growth arrest and apoptosis. These findings indicate that miR-221 and miR-222 play a significant role in the regulation of ERa expression at the protein level and that they could be potential targets for restoring ERa expression and responding to anti-estrogen therapy in a subset of breast cancers.

Finally, one must recognize that the therapeutic potential of targeting miRNAs involved in breast cancer is due to the association of their dysregulation with tumorigenesis. For example, it has been demonstrated by the work of $\mathrm{Si}$ and colleagues that anti-miR-21 (oncomir) - mediated cell growth inhibition was associated with increased apoptosis and decreased cell proliferation, which could be in part owing to downregulation of the antiapoptotic Bcl-2 in anti-miR-21-treated tumor cells [107]. Anti-miR-21-induced reduction in tumor growth was potentiated by the addition of the chemotherapeutic agent topotecan, an inhibitor of DNA topoisomerase I, suggesting that suppression of the oncogenic miR-21 could sensitize tumor cells to anticancer therapy [107]. Conversely, in study by Saito et al. it was demonstrated that certain miRNAs (e.g., miR-127) were upregulated in tumor cells but not in normal cells, suggesting that they are subject to epigenetic silencing. In addition, the proto-oncogene BCL6, a potential target of miR-127, was translationally downregulated after treatment [108]. Results revealed that DNA demethylation and histone deacetylase inhibition can activate the expression of miRNAs that may act as tumor suppressors, therefore presenting another novel therapeutic strategy for the prevention and treatment of malignancy [108].

\section{IMAGING MicroRNAs}

Molecular imaging methods were developed for different cellular targets, including proteins and peptides biomarkers, which are involved in various cellular processes. Optical imaging methods have recently been developed to detect and monitor the functions of microRNAs in intact cells by noninvasively imaging them in living animals (Table 1). However, no radionuclide- based imaging modalities 
such as PET, SPECT and MRI have been explored to investigate the expression level, functional status, and therapeutic role of microRNAs either in cells or in living animals. Prior to the introduction of imaging methods, microRNA detection was accomplished by using various conventional methods such as RT-PCR, northern blot, and microarray analysis. Given the limitations in technical efficiency, and complexity of miRNA-mediated cellular processes, conventional methods are not ideal for carrying out in-depth investigations. Imaging has the advantages of being able to monitor miRNA-mediated cellular process in intact cells and in living animals repeatedly over time, and is thus a more powerful tool than the conventional assay methods. An example of this is fluorescence-based imaging, which employs fluorescent proteins and many synthetic fluorophores. In addition, very recently bioluminescence-based imaging methods such as firefly luciferase (Fluc), Renilla luciferase (Rluc) and Gaussia luciferase (GLuc), were used to study the mechanism and role of miRNA-mediated gene expression and downstream signaling regulations.

Table I: Cancer specific microRNAs and their downstream targets.

\begin{tabular}{|c|c|c|c|c|}
\hline miRNA & Tumor type & Target gene & Role & $\begin{array}{l}\text { Im- } \\
\text { aging }\end{array}$ \\
\hline $\begin{array}{l}\text { miR-122 [142] } \\
\text { miR-101 [143] }\end{array}$ & $\begin{array}{l}\text { Hepato cellular } \\
\text { carcinoma }\end{array}$ & $\begin{array}{l}\text { MDR-1, GST-ח, MRP } \\
\text { Bcl-w } \\
\text { cyclin B1[5] }\end{array}$ & $\begin{array}{l}\text { liver specific miRNA downregulating the set of target } \\
\text { genes }\end{array}$ & \\
\hline miR-409-3p [144] & Gastric tumor & PHF10 & Suppressed the expression of Radixin (RDX) & \\
\hline $\begin{array}{l}\text { miR-508-3p }{ }^{[145]} \\
\text { miR-509-3p }{ }^{[145]}\end{array}$ & Renal cell carcinoma & & $\begin{array}{l}\text { overexpression suppressed the proliferation of RCC cells, } \\
\text { induced cell apoptosis, and inhibited cell migration in vitro }\end{array}$ & \\
\hline $\begin{array}{l}\operatorname{miR}-1 / \\
\operatorname{miR}-206[146] \\
\operatorname{miR}-29[147] \\
\end{array}$ & rhabdomyosarcoma & $\begin{array}{l}\text { PAX3 } \\
\text { CCND2 }\end{array}$ & $\begin{array}{l}\text { Downregulation of the miRNAs stabilizes the expression of } \\
\text { PAX3 and CCND2 in embryonal and alveolar rhabdomy- } \\
\text { osarcoma types }\end{array}$ & [109] \\
\hline miR-196b [148] & Gastric cancer & ETS2 & $\begin{array}{l}\text { (ETS)-2, a transcriptional modulator suppressed the ex- } \\
\text { pression of miR-196b }\end{array}$ & \\
\hline $\begin{array}{l}\text { miR-203 [149] } \\
\text { miR-200c, miR-205 } \\
\text { and miR-211[9][150] }\end{array}$ & Melanoma & $\begin{array}{l}\text { E2F3a } \\
\text { E2F3b } \\
\text { ZBP-89 }\end{array}$ & $\begin{array}{l}\text { reduction of E2F3a, E2F3b, and ZBP-89 protein level, which } \\
\text { are highly expressed in human malignant melanoma, } \\
\text { Mewo cells }\end{array}$ & \\
\hline $\begin{array}{l}\text { miR-15 } \\
\text { miR-16 [31] }\end{array}$ & CLL & BCL2 & $\begin{array}{l}\text { Bcl2 repression by miR-15 and miR-16 could induce apop- } \\
\text { tosis }\end{array}$ & [119] \\
\hline $\begin{array}{l}\text { miRNA-199a } \\
\text { miRNA-199a* [151] }\end{array}$ & $\begin{array}{l}\text { Many cancer cell } \\
\text { types }\end{array}$ & $\begin{array}{l}\text { MET pro- } \\
\text { to-oncogene }\end{array}$ & $\begin{array}{l}\text { Ectopic expression of miRNA-199a and miRNA-199a* } \\
\text { induced apoptosis in many cancer cell types through a } \\
\text { caspase-dependent and a caspase-independent pathways } \\
\text { respectively }\end{array}$ & \\
\hline miR-7 [152, 153] & $\begin{array}{l}\text { Many cancer cell } \\
\text { types }\end{array}$ & EGFR & $\begin{array}{l}\text { inhibiting the Akt pathway by targeting upstream regula- } \\
\text { tors Ras } 1 \text { or Ras } 2\end{array}$ & \\
\hline miR-106a 363 [154] & T-cell leukemia & Kis2 & & \\
\hline $\begin{array}{l}\text { MiR-126 } \\
\text { miR-2155] }\end{array}$ & $\begin{array}{l}\text { pancreatic cancer } \\
\text { prostrate cancer }\end{array}$ & $\begin{array}{l}\text { ADAM9 } \\
\text { MARKS, ANP32A, } \\
\text { SACA4 }\end{array}$ & $\begin{array}{l}\text { tumor suppressor } \\
\text { apoptosis resistance, motility, and invasion }\end{array}$ & \\
\hline miR-17-5p [157] & $\begin{array}{l}\text { Hepatocellular Car- } \\
\text { cinoma }\end{array}$ & & & \\
\hline $\operatorname{miR}-17 / 92^{[158]}$ & prostrate cancer & $\begin{array}{l}\text { MnSOD, GPX2, } \\
\text { TRXR2 }\end{array}$ & $\begin{array}{l}\text { suppress the tumorigenicity of prostate cancer through } \\
\text { inhibition of mitochondrial antioxidant enzymes }\end{array}$ & \\
\hline miR-10b [39, 159] & $\begin{array}{l}\text { prostate cancer, } \\
\text { mammary tumor }\end{array}$ & Tiam1 & $\begin{array}{l}\text { inhibition of miR-10b may be used to prevent primary } \\
\text { tumors from becoming metastatic }\end{array}$ & \\
\hline $\begin{array}{l}\mathrm{miR}-24 / \mathrm{miR}-629 / \mathrm{H} \\
\text { NF4alpha/miR-124 } \\
\text { /STAT3/IL-6R [160] }\end{array}$ & liver cancer & STAT3, IL-6R & $\begin{array}{l}\text { Positive loop create perturbations, amplify and perpetuate } \\
\text { the knock-down of HNF4alpha }\end{array}$ & {$[121]$} \\
\hline $\begin{array}{l}\text { miR-29 family } \\
29 a, 29 b, 29 c, 29 s[46]\end{array}$ & $\begin{array}{l}\text { Non-small cell lung } \\
\text { cancer }\end{array}$ & DNMT-3A \& 3B & intriguing complementarities to the 3'-UTRs of DNMT & \\
\hline $\operatorname{miR}-221 / 222^{[161,162]}$ & $\begin{array}{l}\text { Non-small cell lung } \\
\text { cancer }\end{array}$ & PTEN and TIMP3 & induce TRAIL resistance and enhance cellular migration & {$[114]$} \\
\hline $\operatorname{miR}-15 / 16$ [163] & $\begin{array}{l}\text { lung adenocarcino- } \\
\text { ma }\end{array}$ & $\begin{array}{l}\text { CCND1, CCND2, } \\
\text { CCNE1 }\end{array}$ & $\begin{array}{l}\text { Induce arrest in } \mathrm{G}(1)-\mathrm{G}(0) \text { and suppress metastatic condi- } \\
\text { tion }\end{array}$ & \\
\hline miR-200 [48] & $\begin{array}{l}\text { lung adenocarcino- } \\
\text { ma }\end{array}$ & Flt1/vegfR1 & suppress metastatic condition & \\
\hline hsa-miR-200c [51] & colorectal cancer & MAPKKK3, eIF-4E & function as oncogenes & \\
\hline miR-16 [164] & Colorectal cancer & COX-2 & $\begin{array}{l}\text { ability of elevated levels of HuR to antagonize miR-16 } \\
\text { function }\end{array}$ & \\
\hline
\end{tabular}




\begin{tabular}{|c|c|c|c|c|}
\hline miR-155 [165] & Colorectal cancer & $\begin{array}{l}\text { hMSH2, hMSH6, } \\
\text { hMLH1 }\end{array}$ & Inactivation of mismatch repair & [122] \\
\hline miR-34 [166] & Colorectal cancer & SIRT1 & apoptosis only in colon cancer cells with wild-type p53 & \\
\hline miR-17-92 [167] & colonocytes & TSP-1 and CTGF & $\begin{array}{l}\text { Upregulated in colonocytes, which coexpresses K-Ras, } \\
\text { c-Myc, and p53 impaired activity }\end{array}$ & \\
\hline $\begin{array}{l}\text { miR15 } \\
\text { miR16 [31] }\end{array}$ & $\begin{array}{l}\text { B-cell chronic lym- } \\
\text { phocytic leukemia }\end{array}$ & & $\begin{array}{l}\text { deleted or down-regulated in the majority }(\approx 68 \%) \text { of CLL } \\
\text { cases }\end{array}$ & \\
\hline $\begin{array}{l}\text { miR-155[168] } \\
\text { miR-21 } \\
\text { miR-210 [54] }\end{array}$ & $\begin{array}{l}\text { Diffuse large B-cell } \\
\text { lymphoma }\end{array}$ & & highly expressed in DLBCL & \\
\hline bic/miR-155 [169] & Lymphoma & C-MAF & $\begin{array}{l}\text { homeostasis and function of the immune system in lym- } \\
\text { phocytes }\end{array}$ & \\
\hline miR-19 [57] & $\begin{array}{l}\text { T-cell acute lym- } \\
\text { phoblastic leukemia }\end{array}$ & $\begin{array}{l}\text { BIM, PTEN, } \\
\text { PRKAA1, PPP2R5e }\end{array}$ & $\begin{array}{l}\text { coordinate clamp-down on several regulators of phospha- } \\
\text { tidylinositol-3-OH kinase-related survival signals }\end{array}$ & \\
\hline $\operatorname{miR}-15 / 16[170]$ & Follicular lymphoma & & $\begin{array}{l}\text { increased proliferative capacity and a 'late' germinal center } \\
\text { B-cell phenotype }\end{array}$ & \\
\hline $\begin{array}{l}\text { miR-216 [171] } \\
\text { miR-196a } \\
\text { miR-196b [172] } \\
\end{array}$ & $\begin{array}{l}\text { Pancreatic Ductal } \\
\text { Adenocarcinoma }\end{array}$ & & $\begin{array}{l}\text { Downregulation of miR-216 } \\
\text { Upregulation of miR-196a \& b }\end{array}$ & \\
\hline $\mathrm{miR}-221 / 222[173]$ & Breast cancer & $\begin{array}{l}\text { p27(Kip1) } \\
\text { TRSP1 }\end{array}$ & $\begin{array}{l}\text { p27 levels significantly diminished in tamoxifen-resistant } \\
\text { cells } \\
\text { promote EMT }\end{array}$ & \\
\hline $\operatorname{miR}-21^{[174]}$ & Breast cancer & $\begin{array}{l}\text { TPM1 } \\
\text { PDCD4 }\end{array}$ & Suppression of miR-21 can inhibit tumor growth & \\
\hline miR-107/103 [175] & Breast cancer & Dicer, let-7 & $\begin{array}{l}\text { Dicer inhibition by miR-107/103 steers epithelial cancer } \\
\text { toward a less-differentiated, mesenchymal fate to foster } \\
\text { metastasis }\end{array}$ & \\
\hline miR-17-5p [176] & Breast cancer & $\begin{array}{l}\text { HBP1 } \\
\text { Wnt/b-catenin }\end{array}$ & $\begin{array}{l}\text { cell invasion and migration by suppressing HBP1 } \\
\text { activation of Wnt/b-catenin }\end{array}$ & \\
\hline $\operatorname{miR}-155[177,178]$ & Breast cancer & SOCS1, FOXO3a & $\begin{array}{l}\text { bridge between inflammation and cancer } \\
\text { regulates cell survival, growth, and chemosensitivity }\end{array}$ & \\
\hline miR-23a & & & & [115] \\
\hline Pri-miR-9 & $\begin{array}{l}\text { Mouse embryonic } \\
\text { carcinoma }\end{array}$ & & & [116] \\
\hline miR-221 & $\begin{array}{l}\text { papillary thyroid } \\
\text { carcinoma }\end{array}$ & & & [118] \\
\hline miR-20 & & & & [120] \\
\hline miR-9 & & $\begin{array}{l}\text { transferrin receptor } \\
\text { (TfR) }\end{array}$ & & [124] \\
\hline let-7 & $\begin{array}{l}\text { Lung adenocarci- } \\
\text { noma }\end{array}$ & Ras gene & & [125] \\
\hline
\end{tabular}

\section{Fluorescence-based miRNA imaging}

Mature miRNAs are known to bind their respective target sites in the untranslated regions (UTRs) of the target mRNA. This observation has led to the development of fluorescence-based reporter imaging strategies to monitor the functional status of miRNAs that were either endogenously expressed or transfected to express. Fluorescent reporters have a coding sequence of green fluorescent protein (GFP), and three perfect or imperfect target sequences of miR-1 or miR-204 in the $3^{\prime}$ UTR region were used to study miRNA-mediated gene silencing, and also to monitor the processing of exogenously introduced pri-miRNA-1 [109]. Adopting the same strategy and reporter gene but with the control of ubiquitously expressed phosphoglycerate kinase (PGK) promoter, Brown et al. (2006) have constructed a lentiviral vector to monitor and optimize the expression of transgene in hematopoietic lineages with four tandem copies of miRNA perfect complementary target sequences to miR-30a, miR-142-5p, or miR-142-3p [110]. It was also observed that human U937 monocytes and primary dendritic cells transduced with LV-PGK-GFP-142-3pT showed an over 100-fold reduction in transgene expression when compared with LV-PGK-GFP cells transduced with similar vector copies per genome. In addition, they could image miRNA regulation using a bidirectional lentiviral vector comprising miR-142-3pT in the 3'-UTR of the GFP and a low affinity nerve growth factor receptor ( $\triangle$ LNGFR) that expressed both transgenes in 293T cells, whereas only LNGFR is expressed in monocytes, suggesting that the repression of miR target has tagged GFP. This valuable monitoring tool with four miR target sites for Let-7a, miR-15a, miR-16, miR-17-5p, miR-145, 
miR-218, miR-223, miR-326, and a scrambled sequence (scrT) was transduced in 293T, U937, and Huh7 cells, and the expression level of transgenes was measured by fluorescence-activated cell sorting (FACS) and RT-qPCR analysis that reflected the level of miRNA mediated suppression at protein and RNA level respectively. Using this method of imaging, they concluded that the miRNA-mediated suppression occurred mostly by RNA degradation, although some vectors facilitated high protein production, rather than RNA suppression [111].

In 2009, Kato et al. developed a retroviral vector system to monitor miR-133, a muscle-specific miRNA that enhanced the proliferation of myoblasts during myogenic differentiation in living muscle cells, and the system was successfully evaluated during myogenesis in C2C12 mouse myoblast cells [112]. The vector system was designed in such a way as to express two different color reporter proteins, GFP and RFP. GFP's expression was controlled by LTR promoter, and three copies of complementary sequences against miR-133 were inserted in tandem downstream to GFP sequence and upstream of CMV promoter, which controlled RFP expression. Expression of miR-133 could reduce the level of GFP, as miR-133 binds to the target complementary sequences, but the expression of RFP was unaffected, and the RFP cassette was therefore used as an internal control for normalization [112].

The sensitivity and robustness of this dual-color miRNA monitoring system was extended to image living animals by adenoviral vector system. Lentiviral vector was used in place of retroviral vector to construct the dual-color miRNA imaging system, in which SV40 promoter drove the expression of GFP in the reverse direction relative to the vector LTR, while PGK promoter controlled the expression of RFP. Three tandem repeats of a target sequence completely complementary to the double-stranded region of VAI RNA were incorporated between GFP and the poly (A) signal sequence. The expression of adenovirus-derived miRNAs had selectively induced a reduction in GFP mRNAs containing the target sequences of the miRNAs, without affecting independent expression of RFP that acted as an internal control in the same vector to avoid integrated-site dependency of proviral vector [113].

Therapeutic agents may be used simultaneously as molecular imaging agents, and this strategy facilitates the study of therapeutic efficacy and other consequences of a particular therapeutic molecule. MicroRNA-221 is highly expressed in papillary thyroid carcinoma; it has therefore been treated as a therapeutic target in thyroid tumor. In 2012, Kim et al. have developed a cancer targeting theragnostic probe using
AS1411 aptamer and miRNA-221 molecular beacon (miR-221-MB)-conjugated magnetic fluorescence (MF) nanoparticle (MFAS-miR-221-MB) to simultaneously image miR-221 expression, and to inhibit miR-221mediated cancer development [114]. MFAS miR-221-MB is designed with a pair of long and short oligonucleotides capable of partially binding to each other at complementary sequences. The long oligonucleotide has a mature miRNA-221 binding sequence flanked with an amino group and a disulfide linkage at $5^{\prime}$ end and Cy5 at $3^{\prime}$ end, whereas the short oligonucleotide was linked with a black hole-quencher 2 (BHQ 2) molecule at the 5'-end to nullify the Cy5 fluorescence signal. AS1411 aptamer was used to target the nucleolin protein so as to lead the MFAS-miR-221-MB inside the cell. This device was incorporated into magnetic fluorescent (MF) nanoparticles to make a complete theragnostic probe. The specificity of this molecular beacon was assessed by applying the molecule to fifteen different cancer cell lines: U-87MG (glioblastoma), PC-12 (adrenal gland/ pheochromocytoma), F11 (neuroblastoma), C6 (astrocytoma), HepG-2 (hepatocellular carcinoma), SK-Hep-1 (hepatocellular carcinoma), Caco-2 (colon adenocarcinoma), CT-26 (colon adenocarcinoma), TPC-1 (papillary thyroid carcinoma), NPA (papillary thyroid carcinoma), U-2OS (osteogenic sarcoma), HeLa (cervical cancer), A549 (non-small lung carcinoma), PC-3 (prostate cancer) and F9 (testicular teratoma) and six normal cell lines, including MSC (mesenchymal stem cell), F3 (neuronal stem cell), CHO (ovarian cell), 293 (kidney epithelial cell), L132 (lung epithelial cell), and TM-4 (Sertoli cell) cells. MFAS-miR-221-MB is therefore a potentially versatile theragnostic molecule, with a replacement of respective miRNA expressed in other cancer types for simultaneous therapy and imaging [114].

\section{Bioluminescence-based miRNA imaging}

Bioluminescence-based optical imaging (BLI) has been widely used to monitor the molecular changes in living cells and in small animal models, because it displays background-free signal as compared to fluorescence-based imaging signals. Firefly luciferase (Fluc) was predominantly used in various optical imaging strategies as it emits light (562-610 nm) with reduced tissue attenuation, whereas Gaussia luciferase (Gluc) emits light with a 1000-fold intensity when compared to Renilla luciferase (Rluc) and Fluc-catalysed light intensity. However, Gluc and Rluc emit light in the $460 \mathrm{nM}$ range, which results in significant light absorption, compromising the real signal. In addition, Fluc and Gluc/Rluc uses different substrates (D-luciferin and coelenterazine are respective substrates for Fluc and Gluc/Rluc) and provides 
the advantage of multiplexing to monitor multiple events simultaneously. Due to these benefits in optical imaging, BLI was used in various miRNA monitoring imaging systems. It has been employed to investigate various molecular stages of miRNA processing and its involvement in different molecular processes, as well as its implications in cancer. MicroRNA maturation involves a number of molecular transformations in nucleus and cytoplasm. To start with, primary miRNA (pri-miRNA) is transcribed from genomic DNA by RNA polymerase II and sequences in $5^{\prime}$-upstream region of genomic miRNA that control the transcription of pri-miRNA, followed by the subsequent processing by Drosha and Dicer, but the detailed mechanism behind posttranscriptional regulation of miRNA has not been investigated thoroughly. To simultaneously understand and monitor transcription of pri-miRNA and the activity of mature miRNA in vivo, Lee et al. designed and applied a dual reporter system which contained a Fluc sequence under the control of miR-23a promoter (miR23P639/Fluc) and Gluc sequence tagged with three copies of miR-23a target sequence in the UTR region just before the poly (A) tail under the control of cytomegalovirus (CMV) promoter (CMV/Gluc/3xPT_mir23) [115]. The changes in Fluc signal indicated the transcriptional level of miR-23a promoter, whereas suppression of Gluc signal represented mature miR-23a activity. To validate this dual reporter system, HeLa cells were transfected with CMV/Gluc/3xPT_miR-23 vector to detect repression of Gluc activity by endogenous miR-23a; 293T cells were co-transfected with miR23P639/Fluc and CMV/Gluc/3xPT_miR-23 vectors to look for the exogenous over-expression of Fluc activity and repression of Gluc activity. The dual reporter system was shown to be an efficient BLI monitoring system in vivo when nude mice were subcutaneously grafted with miR-23P639/Fluc and CMV/Gluc/3xPT_miR-23 vectors-co-transfected HeLa and 293T cells (Figure 2). Following the same method, Ko et al. in 2008 developed a bioluminescent luciferase reporter gene system to monitor the endogenous expression of pri-miR-9s during neuronal differentiation in P19 cells, a mouse embryonic carcinoma cell line. pGL3 basic promoter-less reporter vector was cloned with $1343 \mathrm{bp}$ fragment upstream of the pri-miR-9-1 from human genomic DNA, and the Fluc activity that indicated the promoter activity of pri-miR-9-1 during retinoic acid-induced neuronal differentiation was measured. Furthermore, to characterize the minimal region of $1343 \mathrm{bp}$ fragment, it was split into five different segments by PCR, 1387 to 44 bp (miR-9-1PN1_Fluc), 846 to $44 \mathrm{bp}$ (miR-9-1PN2_Fluc), 530 to 44 bp (miR-9-1PN3_Fluc), 236 to $44 \mathrm{bp}$ (miR-9-1PN4_Fluc), and 135 to $44 \mathrm{bp}$
(miR-9-1PN5_Fluc;), cloned into promoter-less vector and transfected into P19 cells. Luciferase assay was performed two days post-treatment of P19 cells with retinoic acid. Of these five different constructs, miR9-1PN3_Fluc showed greater Fluc signal after neuronal differentiation when compared to other four truncated promoter constructs, and this result indirectly indicated the endogenous level of pri-miR9-1 during neurogenesis. In addition, this shows that negative promoter elements of pri-miR9-1 transcription may be involved in the upstream region between -846 and $-531 \mathrm{bp}$, and that positive element may be involved between 530 and $237 \mathrm{bp}$. Thus, the use of miR9-1PN3_Fluc construct was proposed to be useful for in vivo imaging of gene expression controlled by endogenous pri-miR-9 during neurogenesis. This imaging system was also used to monitor the endogenous expression of pri-miR9 in mice by subcutaneously implanting P19 cells transfected with miR9-1PN3_Fluc construct. The Ko group also designed a Gluc-based imaging system to study the expressions of mature miR9 and miR9* during neurogenesis by inserting three copies of perfectly complementary sequences of mature miR-9 (CMV/ Gluc / 3xPT_miR-9) or miR-9* (CMV/ Gluc / 3xPT_miR-9*). The GLuc activities of CMV/ Gluc / 3xPT_miR-9 and CMV/Gluc/3xPT_miR-9* were repressed by cognate mature miR-9 and miR-9*, respectively, when miR-9 or miR-9* was present in the cells. HeLa cells were used to normalize the Gluc activities by transfecting pre-miR9 or pre-miR9*, as they express no mature miR9. In 2009, the same group used a Gluc reporter vector bearing 99 nucleotides from the 3 '-UTR of the c14orf24 gene containing a miR124a seed sequence under the control of a CMV promoter to image miR124a-regulated repression in neuronal differentiation of P19 cells, and the same system was established for in vivo imaging in mice [116].

MicroRNAs such as miR-146b, miR-221, and miR-222 have been shown to be upregulated in papillary thyroid carcinoma (PTC), the most common malignant thyroid cancer in human. To evaluate the regulation and the implication of miR-221 in PTC specifically with homeobox B5 (HOXB5), a gene known to be directly regulated by miR-221, in 2008, Kim et al. developed a Gluc-based imaging system that contains a seed sequence of mature miR-221 in the UTR of HOXB5 after the Gluc stop codon. They constructed three different plasmid vectors: CMV/Gluc-SR, containing 100-base pair (bp) oligonucleotides near the seed region (SR) that binds miR-221 in the 3' UTR of HOXB5; CMV/Gluc_3xSR, containing 3 repeats of the $34-b p$ SR that binds miR-221 in the 3' UTR of HOXB5; and CMV/Gluc_MT, containing completely changed se- 
quences of the SR in the 3' UTR of HOXB5. They were transfected into NPA, a human PTC cell line, co-transfected with pre-miR-221. Gluc activity with endogenous miR-221 was slightly decreased, but significantly decreased with the co-transfection of exogenous pre-miR-221 [117]. In 2009, they developed another Gluc based imaging system, CMV/Gluc-3xPT_miR-221, in which three perfect complementary target sequence repeats of mature miR-221 were incorporated in the 3'-UTR of Gluc, and a significant reduction of Gluc activity was observed due to endogenous miR-221 in HT-ori3, NPA, and TPC-1 cells. The same imaging system was shown to be efficient in monitoring miR-221 function in vivo, as was shown by implanting NPA cells that were transfected with CMV/Gluc-3xPT_miR-221 [118].

MicroRNA-16 was already proven to inhibit prostate cancer cell proliferation and invasion by targeting CCND1 (cyclin D1), WNT3A, and BCL2. To further validate this observation, Takeshita et al. (2010) developed a dual-luciferase imaging system that monitors the therapeutic value and delivery status of synthetic miR-16 in prostate cancer xenograft model. The prostate cancer cells, PC-3M-luc, were transfected with pGL4.75 [HRuc/CMV]-Bcl2 3'UTR, in which 3'UTR of Bcl2 was inserted in pGL4.75 vector downstream to hRluc sequence, and the clones expressed both luciferase genes were used for xenograft model. Synthetic miR-16/atelocollagen complex was administered to mice after nine weeks of tumor implantation through tail vein, and Rluc luminescence was found to be reduced by less than $50 \%$ when compared to signal obtained prior to treatment. In addition, the same system confirmed the miR-16 mediated downregulation of $\mathrm{Bcl} 2$, which helped establish the metastatic tumor inhibitory role of the aforementioned microRNA [119].
A

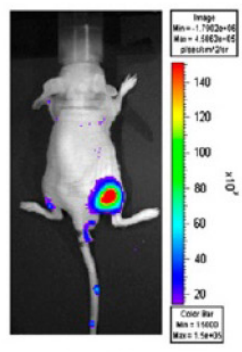

HeLa_Fluc

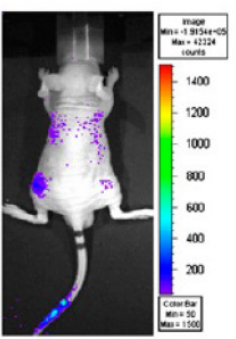

HeLa_Gluc
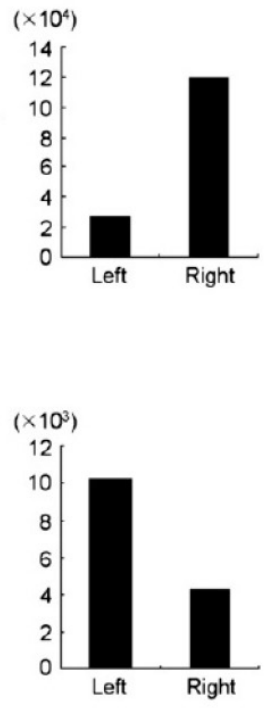

B
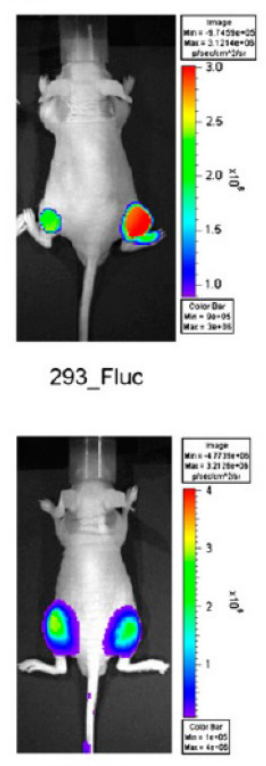

293_Gluc
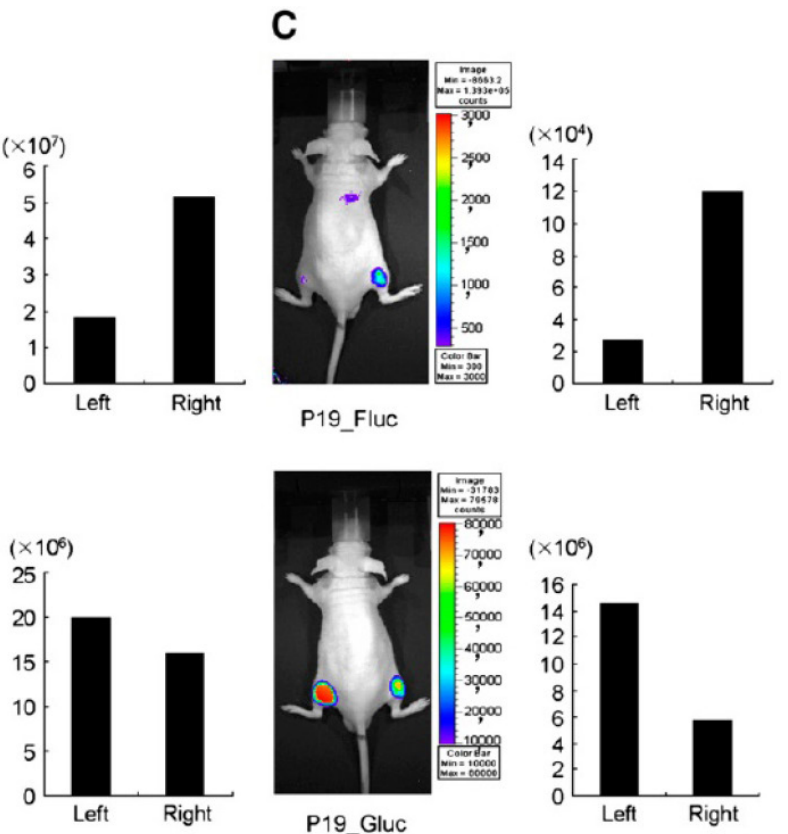

Figure 2. In vivo visualization of expression of pri-miR-23a transcripts and activity of mature forms of miR-23a in nude mice. (A) HeLa cells, (B) 293 cells, and (C) undifferentiated PI9 cells were transfected with miR23P639/Fluc and CMV/Gluc/3xPT_mir23, and were grafted (I X I0 ${ }^{7}$ cells) to right side of mice. The same cells transfected with PGL3_basic and CMV/Gluc were grafted to left side as controls. Quantitative data from imaging in vivo were obtained by $\mathrm{ROI}$ analysis and are shown next to each small-animal picture. Gluc images were acquired first with coelenterazine, and then Fluc images were then acquired with D-luciferin. When viewing Fluc images, pay attention to increased bioluminescence on right side of grafted cells expressing pri-miR-23a transcripts. When viewing Gluc images, note the decreased bioluminescence on right side compared with luciferase activity on left-sided CMV/Gluc controls, disclosing mature miR-23a activities. Fluc activities increased in all animals on right side, and Gluc activities decreased in HeLa and PI 9 cells, but decreased the least in 293 cells transfected with CMV/Gluc/3xPT_mir23 on right side.

\section{In vitro chemiluminesce detection system for quantitative evaluation of miRNAs in cells ly- sates}

MicroRNA detection in live cells and small animals was made possible with various fluorescence and bioluminescence-based reporter gene imaging methods in which different sets of plasmid and viral vectors were employed. Plasmid and viral vector-based imaging systems could be used only in live cells and animals to monitor miRNAs that are endogenously expressed or exogenously transfected to express. To simply monitor the miRNA level in vitro Ma et al. (2011) developed a sensitive chemiluminescence-based miRNA detection method in which 
3'-amino-modified LNA-DNA oligonucleotide probes complementary to the respective miRNA were immobilized on the cover slip and the miRNA sample was hybridized with the probe. Subsequently, the miRNA-probe hybrid was allowed to react with a mixture of poly(U) polymerase and UTP, and the resulting PPi was converted to ATP with the help of adenosine phosphosulfate (APS) and ATP sulfurylase. Eventually, D-luciferin and firefly luciferase were added and visualized by chemiluminescence microscopy imaging with an ultrasensitive intensified charge-coupled device (ICCD) camera. It was very sensitive and efficient when compared to other miRNA detection methods, such as northern blotting, electrochemical assay, fluorometric assay, surface plasmon resonance (SPR) imaging, and fluorescence correlation spectroscopy, and the chemiluminescence limit of miRNA detection was found to be $50 \mathrm{fM}$. Also, the multiplexing capability of the detection system was demonstrated with miR-20 and let-7a LNA probes that had dissimilar sequences [120]. However, this method is not as sensitive as the RT-PCR assay currently used for in vitro miRNA detection.

Modern imaging methods were developed for monitoring expression levels of miRNAs and the associated target genes independently. Ponomarev et al. (2011) developed cytometry-based imaging protocol for simultaneous visualization and quantification of miRNAs and their putative target genes. It was validated in a neuronal cell line, NIE115, with miR-124-FITC, a miR-124 specific probe, and cyclin dependent kinase 6 (CDK6) primary antibodies and AlexaFluor-660-conjugated secondary antibody. The images were acquired and analyzed by ImageStream 100 imaging cytometer and IDEAS software. The method was found to be sensitive and efficient for quantitative evaluation of miRNA and target expression in individual cells, as it employs the power of different lasers at 405, 488, and $658 \mathrm{~nm}$ to provide good signal separation with little effect on the overall fluorescent signal. Furthermore, its ability to analyze very small numbers of cells and characterize miRNAs and target expression in diverse cell subsets, including stem cells, immune cells, solid tissues and tumors, makes it a useful imaging technique. It has been identified as an ideal imaging method to simultaneously detect and quantify miRNA and target genes for isolated primary cells with an efficiency comparable to that attained with cultured cells [121].

In 2009, Nuovo et al. designed RT-PCR in situ hybridization method to detect miRNA precursors. This method comprises three applications, RT in situ PCR to detect the miRNA precursors, miRNA in situ hybridization with locked nucleic acid (LNA) probes, and the analysis of putative miRNA targets by im- munohistochemistry co-labeling for the protein of interest. Using this method, miRNA could be detected from paraffin-embedded and formalin-fixed tissue. The protocol included a brief protease digestion, overnight hybridization, low stringency wash and co-labeling by immunohistochemistry using Antidigoxigenin-AP/ NBT/BCIP-based detection. Expression of miRNA miR-155, which is upregulated in lymphoproliferative diseases, such as AIDS and colon cancer, was demonstrated with this hybridization method. Although the versatility of the protocol was demonstrated, it has certain limitations. For example, the primers used for RT in situ PCR were not efficient enough to differentiate the precursor and primary miRNA molecules, and very low concentrations of miRNAs also could not be detected with LNA in situ hybridization method. In addition, certain proteins may demonstrate non-specificity with the immunohistochemistry method [122].

In 2011, Roy et al. designed a microfluidic-assisted microarray with differential interference contrast (DIC) imaging technique to detect miRNA. This is a hybridization-based technique in which the aminated two-segmented oligonucleotide capture probes were immobilized on flat glass slides with a photolithographically-patterned and etched passivation layer, and hybridized with target miRNA strands and then with GNP tagged signaling probes. Roy et al. reported that this array technique can detect 300 copies of target miRNAs in $1.0 \mu$ sample volume [123].

\section{Multimodal imaging}

Application of multimodal imaging is a prerequisite for eliminating the limitations encountered when using optical imaging (e.g., bioluminescenceand fluorescence-based imaging modalities). Tissue attenuation restricts application of optical imaging in revealing therapeutic value of miRNAs in various internal organs cancers. Multimodal imaging resolves these issues by combining superior qualities of two or more imaging modalities. Nanoparticles are suitable imaging agents that facilitate multimodal imaging due to their ability to adopt different imaging molecules in a single imaging compound. A reverse complementary multimodal imaging system was developed to image miR-9 during neurogenesis using transferrin receptor (TfR) and a magnetic fluorescence (MF) nanoparticle-conjugated peptide targeting TfR (MF targeting TfR) (Figure 3). Nanoparticle-targeted TfR is internalized into the cell in the absence of miR-9, and as a result, high fluorescence and low MR signals are generated. By contrast, low fluorescence (signal-off) and high MR signals (signal-on) were observed due to high level expression of miR-9 that re- 
presses TfR expression. This multimodal imaging system also proved to be efficacious in vivo for imaging the involvement of miR-9 in neurogenesis [124].

\section{Other MiRNA Imaging methods}

Optical imaging methods employing bioluminescent and fluorescent reporters are prevalent in preclinical evaluation of miRNA's therapeutic efficiency. Currently, attempts are underway to apply other advantageous imaging methods to image miRNA either directly to study its expression level, or indirectly by targeting proteins linked to pathways controlled by miRNAs. Recently, Cherenkov Luminescence Imaging (CLI) and gamma camera imaging were demonstrated to be useful for evaluating the role of miRNA, let-7, in lung adenocarcinoma A549 cells using human sodium/iodine symporter (hNIS) as a reporter and 3'-UTR sequence of Ras gene (RU) as a target of let-7. Gamma camera imaging $\left(\mathrm{r}^{2}=0.9893\right)$ and radioactivity counting $(0.9779)$ were highly correlated with CLI. As a result, these two imaging methods were identified for the first time as efficient tools for monitoring the expression of let-7 [125].

\section{Imaging Therapeutic role of miRNAs in cancer}

It has been well established that miRNAs govern the expression of genes that take part in different cellular processes and maintain cells homeostasis. Multiple miRNAs can control the expression of single mRNA. By contrast, one miRNA can control the expression of several mRNAs, and a group of miRNAs can influence the upregulation of certain mRNAs, while others can suppress the expression of several other genes so as to maintain the cellular homeostasis. Dysregulation of these miRNAs has been implicated in various types of cancer. In addition, some miRNAs act as oncogenes and others as tumor suppressors by mediating unique molecular mechanisms. Due to this pivotal involvement of miRNAs in cancer development and progression, they are becoming important therapeutic targets for cancer treatment. Various approaches of miRNA-based therapeutic developments are under investigation, most of which falling under two major approaches: 1) inhibition of selective miRNAs, which are overexpressed and contribute to tumorigenesis, and 2) supplementation of selective miRNAs, which are downregulated in tumors.

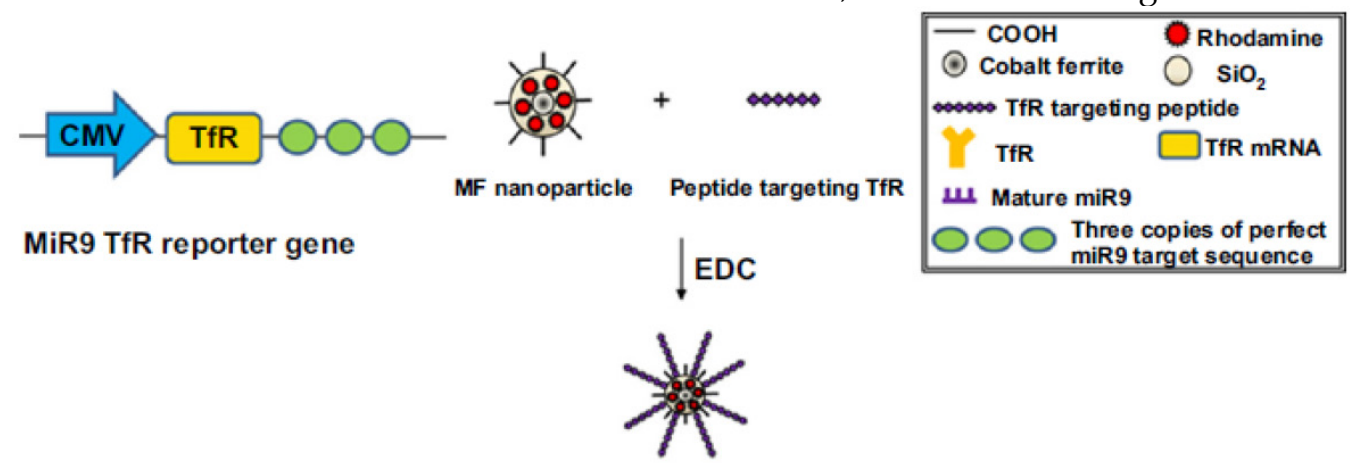

Reverse complementary multimodal reporter probe

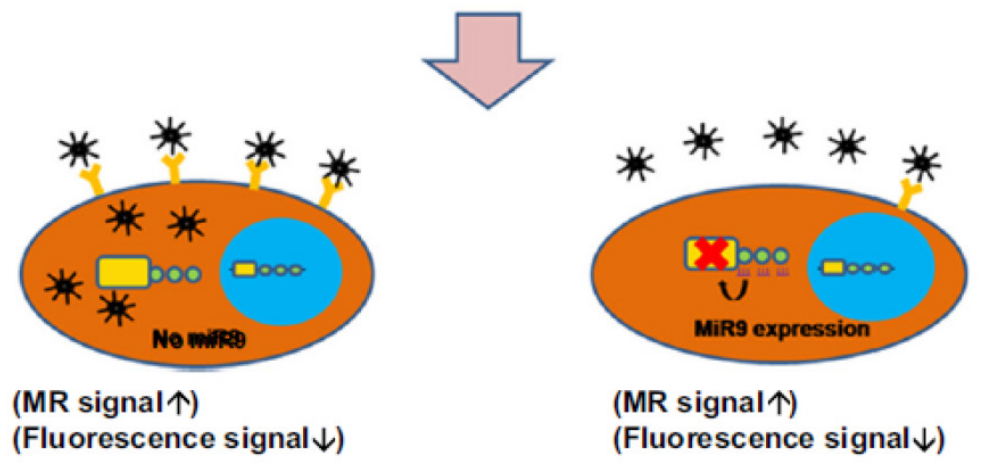

Shematic of the reverse complementary multimodal imaging system

Figure 3. Schematic of the reverse complementary multimodal imaging system.

MicroRNAs from the miR-200 family have been implicated in the progression of polymetastasis from oligometastatic state, which was proposed to be an intermediate stage in metastatic state. MiR-200c was shown to be involved in polymetastasis progression using microRNA-200c enhancement in oligometastatic cell line and oligometastatic-polymetastatic xenograft model [126]. Akinc et al. (2007) developed a lipid-like delivery molecules, lipidoids, to deliver single-stranded antisense 2'-O-methyl (2'-O Me) 
modified complementary oligoribonucleotides targeting miR-122 and tested their efficiency in mouse model. They injected anti-miR-122 formulated with lipidoid ${ }^{98} \mathrm{~N}_{12}-5$, at $5 \mathrm{mg} / \mathrm{Kg}$ for three consecutive days, and examined its efficiency by evaluating silencing of miR-122 function and the upregulation of miR-122 target genes such as Gpx7, Hfe2, Lass6, Slc35a4, Tmed3, Tmem50b, and AldoA [127].

Krutzfeldt et al., (2005) developed chemically modified, cholesterol-conjugated single stranded RNA molecules complementary to specific miRNA called antagomiRs. They administered antagomiRs against miR-16, miR-122, miR-192, and miR-194 intravenously in mice, and observed a marked reduction of corresponding miRNA levels in liver, lung, kidney, heart, intestine, fat, skin, bone marrow, muscle, ovaries, and adrenal gland. To prove the biological significance of miRNA silencing with antagomiR, they targeted miR-122, an abundant liver- specific microRNA and analyzed their target mRNA levels by Affymetrix arrays and reverse transcriptase polymerase chain reaction (RT-PCR). Furthermore, they observed a strong enrichment of miR-122 recognition motif at 3'-untranslated regions (UTR) of upregulated mRNAs by UTR sequence analysis of 9554 mRNAs and a specific miR-122 recognition motif, CACTAC, which corresponds to nucleotides 2-7. The core nucleus sequence of miR-122 was observed in more than $50 \%$ of upregulated mRNAs. The length and concentration of miR-122 antagomiR was optimized to silence endogenous miR-122, and oligomer of 23 to 25 nucleotides was found to be the optimal length for significant silencing of miR-122. However, the silencing efficiency of antagomiR was completely lost when the length was reduced to 19 nucleotides. Addition or even a deletion of 2 nucleotides did not significantly affect the silencing efficiency of miR-122 antagomiR. While testing the consequences of different mismatch numbers in the antagomiR sequence on miR-122 levels and miR-122 targets, four mismatches, two mismatches or a single mismatch at position 19 was found to be sufficient to prevent downregulation of miR-122 and upregulation of three different miR-122 targets (AldoA, Tmed3, and Hfe2), as measured by RT-PCR. Single nucleotide mismatch was identified to be position-dependent in antagomiRs because single nucleotide mismatches at nucleotide 1 and 11 did not prevent downregulation of miR-122 levels or target regulation [128].MiR-126 has been shown to be highly expressed in human endothelial cells. To explore the possible involvement of miR-126 in arteriogenesis and angiogenesis, Solingen et al. (2009) developed a cholesterol-conjugated modified antagomiR RNA with 21 nucleotides in length and a control RNA of identical length but random sequence (Scrambled-miR), and proved that antagomiR-126 specifically silenced miR-126 in endothelial cell, EC-RF24. Using antagomiR-126, they established that miR-126 has no effect on in vitro angiogenesis, cell migration, and proliferation, and in vivo arteriogenesis, and ischemia-induced angiogenesis [129]. We developed a delivery system using biodegradable PEGylated-PLGA-nanoparticles co-encapsulated with chemically modified antagomiRs (antagomiR- 21 and antagomiR-10b), and used firefly luciferase reporter containing $3^{\prime} U T R$ of maspin, miR-21 target gene, to assess the therapeutic efficacy of chemically modified antagomiRs [130] (Figure 4).

In 2003, Boutla et al. applied a strategy of using DNA as bait to silence miRNAs. They custom- synthesized DNA antisense oligonucleotides complementary to 11 different miRNAs, which are known to be expressed and involved in early embryo development in Drosophila, and investigated their efficiency in silencing the miRNAs, and found that they were associated with Drosophila embryo development. DNA antisense oligonucleotides specific to miR-1, miR-2a, miR-3, and miR-13a caused a variety of developmental defects within 48 hours after oligonucleotide injection, while the rest of them elicited partial or no response [131].

Davis et al. (2006) investigated the effect of antisense RNA oligonucleotide (ASO) modifications to confer effective miR-21 silencing by using luciferase reporter vector system. They evaluated the effect of 2 -sugar modifications such as phosphorothioate (PS) oligonucleotides with uniform 2'-O-MOE, 2'-O-Me or $2^{\prime}$-flouro $\left(2^{\prime} \mathrm{F}\right)$ substitution, along with a $2^{\prime}$-O-MOE-PS compound containing seven high affinity LNA substitutions, one at every third position. The results showed a significant increase in affinity compared to DNA with 2'-O-Me $\cong 2$-O-MOE $<2$ '-F $<$ 2'-O-MOE/LNA 24 hours after ASO treatment. No significant cytotoxic effect was observed up to $11 \mathrm{nM}$ ASO treatment [132].

Replacement of miRNAs that are responsible for causing cancer was attempted by many investigators as a therapy for various cancers. It could be accomplished either by transient transfection of double-stranded miRNA mimetics, or by introducing vectors that are capable of overexpressing a specific miRNA. Both of these approaches are aimed at re-establishing miRNA expression prevailing prior to the onset of cancer to keep the homeostatic genes under control. The function of double-stranded miRNA introduced in this fashion was similar to that of the endogenous miRNA in targeting the respective mRNAs. However, this approach had certain limitations, such as instability of the introduced double-stranded miRNA, lack of stable expression of miRNA, and the difficulty in systemic delivery 
[133-135]. These shortcomings could be resolved with another approach, in which specific miRNA-expressing plasmids or viral vectors under control of promoters like Pol II are introduced. This supplements the respective miRNAs for a longer period and the expressed miRNAs follow the endogenous processing mechanism to become mature miRNAs $[136,137]$. Moreover, expression of multiple miRNAs in a single transcript could be achieved. It must be kept in mind that viral vectors pose some risks, such as insertional mutagenesis and redundant immune response, which limit their clinical use.
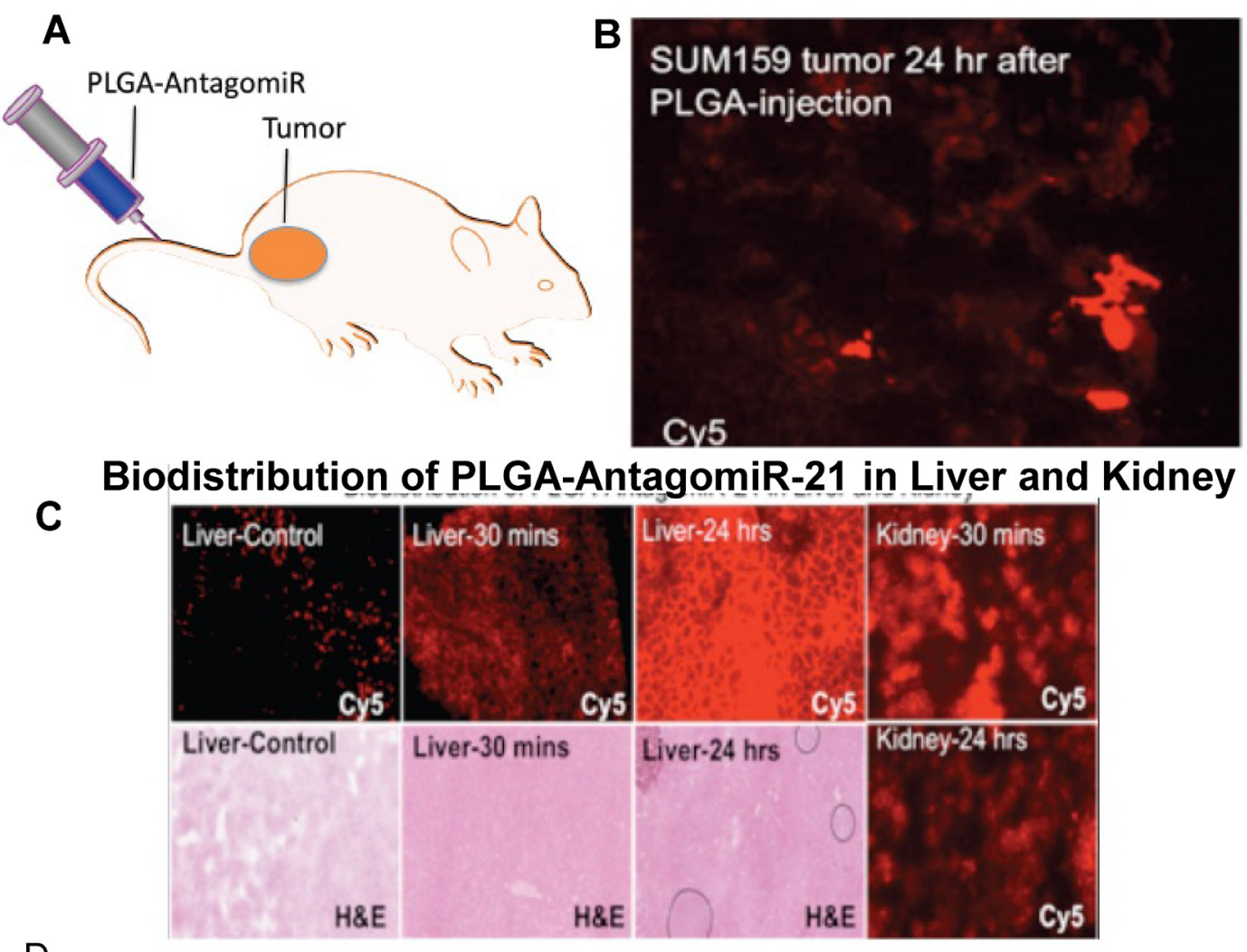

$\mathrm{D}$

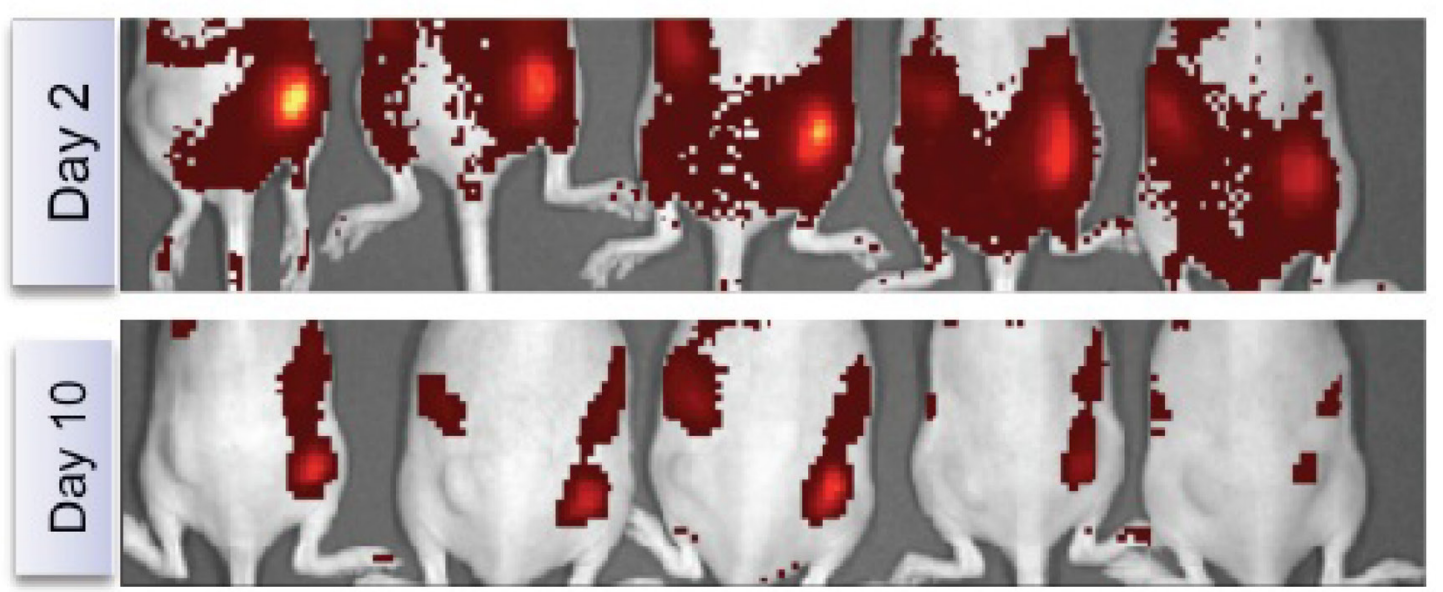

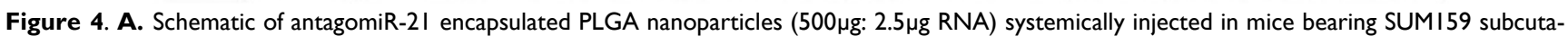
neous tumor, by tail vein. B. Fluorescent microscope image of tumor slices of animals sacrificed 24 hrs after the injection of PLGA-NP-Cy5-antagomiR-2I for released Cy5-antagomiR-2I. C. Fluorescent microscope image of liver and kidney slices of animals sacrificed 30 mins and 24 hrs after the injection of PLGA-NP-Cy5- antagomiR-2I for released Cy5-antagomiR-2I and corresponding H\&E stained slices. D. Optical fluorescence imaging of animals implanted with SUMI59 cells pre-exposed with PLGA-NP-Cy5-antagomiR-2I for 24 hrs. The animals were periodically imaged for Cy5- antagomiR-2I signal. The images shown here are animals imaged on day 2 and day 10 . The images are adjusted in the same scale for comparison. 
MicroRNA sponges are plasmid or viral vectors constructed with multiple target sites complementary to an endogenous miRNA, which were used to suppress specific miRNA targets. They are designed to have multiple miRNA binding sites (4 to 10) at 3'UTR of a reporter gene with a bulge in a position where Argonaute 2 cleaves, and are driven by high expression promoters, such as CMV promoter [138]. Sponges are advantageous over chemically modified antisense oligonucleotides as they are specific to target miRNAs and can be easily delivered using viral vectors in difficult-to-transfect cells (see review [139]). Because the sponge miRNA binding sequences form base pairs with miRNAs seed region, it captures all members of a miRNA seed family. Unlike antisense oligonucleotides, miRNA sponges blocks all the miRNAs belonging to a seed family. MiRNA sponges constructed with bulged multiple binding sites showed a significant inhibition of cell growth when compared to sponges with perfect multiple binding sites. A miR-19 sponge with multiple binding sites was shown to be efficacious to inhibit the growth of WEHI-231 B-cell lymphoma cells, which over-express miRNAs of the miR-17 92 cluster [140]. Although miRNA sponges are efficient in effecting cell growth arrest, they are still primitive in miRNA-based therapy.

\section{Future Directions}

MicroRNAs are emerging as important therapeutic targets, as they play key roles in regulation of oncogenes, tumor suppressor genes, and genes regulating cancer growth, metastasis and apoptosis. Detection of miRNA in circulating blood and from localized tissues is also evolving as new prognostic markers in determining the therapeutic response in different types of cancer, which are difficult to predict due to the shortage of highly effective and sensitive detection methods available for these factors. Since the inception of miRNA research, conventional techniques such as PCR-based methods, northern blot and microarray-based methods are used to investigate their role and implications with various diseases. However, the advancement of miRNA research to reveal the therapeutic role of various miRNAs has been hampered by the shortcomings of routinely usable methods. The versatility and power of molecular imaging can help elucidate the physical and physiological roles of various proteins involved in cellular functions. Recently, molecular imaging methods have been instrumental in accelerating the investigation of miRNAs associated with various diseases, particularly cancer. Optical imagings, such as fluorescenceand bioluminescence-based imaging methods have been used to detect and evaluate the therapeutic effi- cacy of various miRNAs. Besides the applications of optical imaging in miRNA research, other imaging modalities, such as PET, SPECT, MRI, and CT remain to be fully explored to evaluate the therapeutic value of various miRNAs.

Epigenetic modifications were recently shown to control the expression of miRNA coding genes [141]. For example, miRNAs were implicated with DNA methylation and histone modifications. Further investigation of miRNAs associated with epigenetic regulation of cancer may open a venue of miRNA therapeutics. Molecular imaging methods are under evaluation to detect and monitor the epigenetic modifications both in cells and animals. In addition, efforts to image the role of miRNA in carcinogenesis using molecular imaging are underway, which should help realize the full potential of miRNA-targeted cancer therapy.

\section{Summary and Conclusion}

Basic research data on microRNAs are being accumulated from the rapid expansion of insight into their molecular mechanisms and implications for various diseases, especially cancer. Although intensive research is underway, the complete mechanisms by which microRNAs exert control over the expression of various genes have yet to be clearly established. Molecular imaging can greatly facilitate efforts to understand the roles of various miRNAs associated with cancer. However, thus far only optical imaging has been widely developed and used to study the involvement of miRNA in cancer. Applications of optical imaging are limited to preclinical research due to limitations such as tissue attenuation of imaging signals and lack of tomographic informations. As other radionuclide imaging modalities are adopted for this use, the full therapeutic value of miRNAs may be realized in the near future by imaging in human. Development of systematic approaches using miRNAs with specific chemical modifications, an efficient in vivo delivery system, and ability to monitor both miRNAs and their downstream physiological effects will help advance their therapeutic application and lay the foundation for an independent discipline with clinical utility.

\section{Acknowledgements}

We thank Department of Radiology, Stanford University School of Medicine, and NIH-NCI RO1CA161091 (R. Paulmurugan) for funding support and the Canary Center at Stanford, Department of Radiology for facilities and resources. We gratefully acknowledge the constant support and encouragement rendered by Dr. Sanjiv S Gambhir, Chair, De- 
partment of Radiology, and Stanford University School of Medicine.

\section{Competing Interests}

The authors have declared that no competing interest exists.

\section{References}

1. Ambros V: MicroRNA pathways in flies and worms: growth, death, fat, stress, and timing. Cell 2003, 113(6):673-676.

2. Bartel DP, Chen CZ: Micromanagers of gene expression: the potentially widespread influence of metazoan microRNAs. Nat Rev Genet 2004, 5(5):396-400.

3. Sassen S, Miska EA, Caldas C: MicroRNA: implications for cancer. Virchows Arch 2008, 452(1):1-10

4. Lee Y, Ahn C, Han J, Choi H, Kim J, Yim J, Lee J, Provost P, Radmark O, Kim S et al: The nuclear RNase III Drosha initiates microRNA processing. Nature 2003, 425(6956):415-419.

5. Yi R, Qin Y, Macara IG, Cullen BR: Exportin-5 mediates the nuclear export of pre-microRNAs and short hairpin RNAs. Genes Dev 2003, 17(24):3011-3016.

6. Bernstein E, Caudy AA, Hammond SM, Hannon GJ: Role for a bidentate ribonuclease in the initiation step of RNA interference. Nature 2001, 409(6818):363-366

7. Kim VN: MicroRNA biogenesis: coordinated cropping and dicing. Nat Rev Mol Cell Biol 2005, 6(5):376-385.

8. Lau NC, Lim LP, Weinstein EG, Bartel DP: An abundant class of tiny RNAs with probable regulatory roles in Caenorhabditis elegans. Science 2001, 294(5543):858-862.

9. Cai $\mathrm{X}$, Hagedorn $\mathrm{CH}$, Cullen BR: Human microRNAs are processed from capped, polyadenylated transcripts that can also function as mRNAs. RNA 2004, 10(12):1957-1966.

10. Jiang Q, Wang Y, Hao Y, Juan L, Teng M, Zhang X, Li M, Wang G, Liu Y: miR2Disease: a manually curated database for microRNA deregulation in human disease. Nucleic Acids Res 2009, 37(Database issue):D98-104.

11. Ono K, Kuwabara Y, Han J: MicroRNAs and cardiovascular diseases. FEBS J 2011, 278(10):1619-1633.

12. Shafi G, Aliya N, Munshi A: MicroRNA signatures in neurological disorders. Can I Neurol Sci 2010, 37(2):177-185.

13. Zhao Y, Xu H, Yao Y, Smith LP, Kgosana L, Green J, Petherbridge L, Baigent SJ, Nair V: Critical role of the virus-encoded microRNA-155 ortholog in the induction of Marek's disease lymphomas. PLoS Pathog 2011, 7(2):e1001305.

14. Rottiers V, Najafi-Shoushtari SH, Kristo F, Gurumurthy S, Zhong L, Li Y, Cohen DE, Gerszten RE, Bardeesy N, Mostoslavsky R et al: MicroRNAs in Metabolism and Metabolic Diseases. Cold Spring Harb Symp Quant Biol 2011.

15. Jones S, Zhang X, Parsons DW, Lin JC, Leary RJ, Angenendt P, Mankoo P, Carter H, Kamiyama H, Jimeno A et al: Core signaling pathways in human pancreatic cancers revealed by global genomic analyses. Science 2008, 321(5897):1801-1806

16. Parsons DW, Jones $S$, Zhang $X$, Lin JC, Leary RJ, Angenendt $P$, Mankoo $P$, Carter H, Siu IM, Gallia GL et al: An integrated genomic analysis of human glioblastoma multiforme. Science 2008, 321(5897):1807-1812.

17. Costinean S, Zanesi N, Pekarsky Y, Tili E, Volinia S, Heerema N, Croce CM: Pre-B cell proliferation and lymphoblastic leukemia/high-grade lymphoma in E(mu)-miR155 transgenic mice. Proc Natl Acad Sci $U$ S A 2006, 103(18):7024-7029.

18. He L, Thomson JM, Hemann MT, Hernando-Monge E, Mu D, Goodson S, Powers S, Cordon-Cardo C, Lowe SW, Hannon GJ et al: A microRNA polycistron as a potential human oncogene. Nature 2005, 435(7043):828-833.

19. Chan JA, Krichevsky AM, Kosik KS: MicroRNA-21 is an antiapoptotic factor in human glioblastoma cells. Cancer Res 2005, 65(14):6029-6033.

20. Yu F, Yao H, Zhu P, Zhang X, Pan Q, Gong C, Huang Y, Hu X, Su F, Lieberman $\mathrm{J}$ et al: let-7 regulates self renewal and tumorigenicity of breast cancer cells. Cell 2007, 131(6):1109-1123.

21. Akao $Y$, Nakagawa $Y$, Naoe T: let-7 microRNA functions as a potential growth suppressor in human colon cancer cells. Biol Pharm Bull 2006, 29(5):903-906.

22. Johnson SM, Grosshans H, Shingara J, Byrom M, Jarvis R, Cheng A, Labourier E, Reinert KL, Brown D, Slack FJ: RAS is regulated by the let-7 microRNA family. Cell 2005, 120(5):635-647.

23. Peng Y, Laser J, Shi G, Mittal K, Melamed J, Lee P, Wei JJ: Antiproliferative effects by Let-7 repression of high-mobility group A2 in uterine leiomyoma. Mol Cancer Res 2008, 6(4):663-673.

24. Saito Y, Suzuki H, Matsuura M, Sato A, Kasai Y, Yamada K, Saito H, Hibi T: MicroRNAs in Hepatobiliary and Pancreatic Cancers. Front Genet 2011, 2:66.

25. Li C, Nie H, Wang M, Su L, Li J, Yu B, Wei M, Ju J, Yu Y, Yan M et al: MicroRNA-409-3p regulates cell proliferation and apoptosis by targeting PHF10 in gastric cancer. Cancer Lett 2012.

26. Zhai Q, Zhou L, Zhao C, Wan J, Yu Z, Guo X, Qin J, Chen J, Lu R: Identification of miR-508-3p and miR-509-3p that are associated with cell invasion and migration and involved in the apoptosis of renal cell carcinoma. Biochem Biophys Res Commun 2012.
27. Li L, Sarver AL, Alamgir S, Subramanian S: Downregulation of microRNAs miR-1, -206 and -29 stabilizes PAX3 and CCND2 expression in rhabdomyosarcoma. Lab Invest 2012

28. Liao YL, Hu LY, Tsai KW, Wu CW, Chan WC, Li SC, Lai CH, Ho MR, Fang WL, Huang KH et al: Transcriptional regulation of miR-196b by ETS2 in gastric cancer cells. Carcinogenesis 2012

29. Noguchi S, Mori T, Otsuka Y, Yamada N, Yasui Y, Iwasaki J, Kumazaki M, Maruo K, Akao Y: Anti-oncogenic MicroRNA-203 Induces Senescence by Targeting E2F3 in Human Melanoma Cells. J Biol Chem 2012

30. Xu Y, Xia F, Ma L, Shan J, Shen J, Yang Z, Liu J, Cui Y, Bian X, Bie P et al: MicroRNA-122 sensitizes HCC cancer cells to adriamycin and vincristine through modulating expression of MDR and inducing cell cycle arrest. Cancer Lett 2011, 310(2):160-169.

31. Cimmino A, Calin GA, Fabbri M, Iorio MV, Ferracin M, Shimizu M, Wojcik SE, Aqeilan RI, Zupo S, Dono M et al: miR-15 and miR-16 induce apoptosis by targeting BCL2. Proc Natl Acad Sci U S A 2005, 102(39):13944-13949.

32. Lam LT, Lu X, Zhang H, Lesniewski R, Rosenberg S, Semizarov D: A microRNA screen to identify modulators of sensitivity to BCL2 inhibitor ABT-263 (navitoclax). Mol Cancer Ther 2010, 9(11):2943-2950.

33. Kim S, Lee UJ, Kim MN, Lee EJ, Kim JY, Lee MY, Choung S, Kim YJ, Choi YC: MicroRNA miR-199a* regulates the MET proto-oncogene and the downstream extracellular signal-regulated kinase 2 (ERK2). J Biol Chem 2008, 283(26):18158-18166

34. Kefas B, Godlewski J, Comeau L, Li Y, Abounader R, Hawkinson M, Lee I, Fine H, Chiocca EA, Lawler S et al: microRNA-7 inhibits the epidermal growth factor receptor and the Akt pathway and is down-regulated in glioblastoma. Cancer Res 2008, 68(10):3566-3572.

35. Ambs S, Prueitt RL, Yi M, Hudson RS, Howe TM, Petrocca F, Wallace TA, Liu CG, Volinia S, Calin GA et al: Genomic profiling of microRNA and messenger RNA reveals deregulated microRNA expression in prostate cancer. Cancer Res 2008, 68(15):6162-6170.

36. Li T, Li D, Sha J, Sun P, Huang Y: MicroRNA-21 directly targets MARCKS and promotes apoptosis resistance and invasion in prostate cancer cells. Biochem Biophys Res Commun 2009, 383(3):280-285.

37. Sylvestre Y, De Guire V, Querido E, Mukhopadhyay UK, Bourdeau V, Major F, Ferbeyre G, Chartrand P: An E2F/miR-20a autoregulatory feedback loop. J Biol Chem 2007, 282(4):2135-2143.

38. Di Leva G, Briskin D, Croce CM: MicroRNA in cancer: new hopes for antineoplastic chemotherapy. Ups J Med Sci 2012, 117(2):202-216.

39. Ma L, Reinhardt F, Pan E, Soutschek J, Bhat B, Marcusson EG, Teruya-Feldstein J, Bell GW, Weinberg RA: Therapeutic silencing of miR-10b inhibits metastasis in a mouse mammary tumor model. Nat Biotechnol 2010, 28(4):341-347.

40. Takeshita F, Patrawala L, Osaki M, Takahashi RU, Yamamoto Y, Kosaka N, Kawamata M, Kelnar K, Bader AG, Brown D et al: Systemic delivery of synthetic microRNA-16 inhibits the growth of metastatic prostate tumors via downregulation of multiple cell-cycle genes. Mol Ther 2009, 18(1):181-187.

41. Cancer Research UK. Cancer Stats - Cancer Worldwide. Cancer Research UK. 2011.

42. Bosch FX, Ribes J, Cleries R, Diaz M: Epidemiology of hepatocellular carcinoma. Clin Liver Dis 2005, 9(2):191-211.

43. Bushati N, Cohen SM: microRNA functions. Annu Rev Cell Dev Biol 2007, 23:175-205.

44. Lewis BP, Burge CB, Bartel DP: Conserved seed pairing, often flanked by adenosines, indicates that thousands of human genes are microRNA targets. Cell 2005, 120(1):15-20.

45. Hatziapostolou M, Polytarchou C, Aggelidou E, Drakaki A, Poultsides GA, Jaeger SA, Ogata H, Karin M, Struhl K, Hadzopoulou-Cladaras M et al: An HNF4alpha-miRNA inflammatory feedback circuit regulates hepatocellular oncogenesis. Cell, 2011;147(6):1233-1247.

46. Fabbri M, Garzon R, Cimmino A, Liu Z, Zanesi N, Callegari E, Liu S, Alder H, Costinean S, Fernandez-Cymering $\mathrm{C}$ et al: MicroRNA-29 family reverts aberrant methylation in lung cancer by targeting DNA methyltransferases $3 \mathrm{~A}$ and 3B. Proc Natl Acad Sci U S A 2007, 104(40):15805-15810.

47. Mallick R, Patnaik SK, Yendamuri S: MicroRNAs and lung cancer: Biology and applications in diagnosis and prognosis. J Carcinog 2010, 9 .

48. Roybal JD, Zang Y, Ahn YH, Yang Y, Gibbons DL, Baird BN, Alvarez C, Thilaganathan N, Liu DD, Saintigny $\mathrm{P}$ et al: miR-200 Inhibits lung adenocarcinoma cell invasion and metastasis by targeting Flt1/VEGFR1. Mol Cancer Res 2011, 9(1):25-35.

49. Cushing L, Kuang PP, Qian J, Shao F, Wu J, Little F, Thannickal VJ, Cardoso WV, Lu J: miR-29 is a major regulator of genes associated with pulmonary fibrosis. Am J Respir Cell Mol Biol 2011, 45(2):287-294.

50. Corte H, Manceau G, Blons H, Laurent-Puig P: MicroRNA and colorectal cancer. Dig Liver Dis 2012, 44(3):195-200.

51. Xi Y, Formentini A, Chien M, Weir DB, Russo JJ, Ju J, Kornmann M: Prognostic Values of microRNAs in Colorectal Cancer. Biomark Insights 2006, 2:113-121.

52. Young LE, Moore AE, Sokol L, Meisner-Kober N, Dixon DA: The mRNA stability factor HuR inhibits microRNA-16 targeting of COX-2. Mol Cancer Res 2012, 10(1):167-180.

53. Calin GA, Dumitru CD, Shimizu M, Bichi R, Zupo S, Noch E, Aldler H, Rattan $\mathrm{S}$, Keating $\mathrm{M}$, Rai $\mathrm{K}$ et al: Frequent deletions and down-regulation of microRNA genes miR15 and miR16 at 13q14 in chronic lymphocytic leukemia. Proc Natl Acad Sci U S A 2002, 99(24):15524-15529. 
54. Lawrie CH, Gal S, Dunlop HM, Pushkaran B, Liggins AP, Pulford K, Banham AH, Pezzella F, Boultwood J, Wainscoat JS et al: Detection of elevated levels of tumour-associated microRNAs in serum of patients with diffuse large B-cell lymphoma. Br J Haematol 2008, 141(5):672-675.

55. Kulshreshtha R, Ferracin M, Wojcik SE, Garzon R, Alder H, Agosto-Perez FJ, Davuluri R, Liu CG, Croce CM, Negrini M et al: A microRNA signature of hypoxia. Mol Cell Biol 2007, 27(5):1859-1867.

56. Rodriguez A, Vigorito E, Clare S, Warren MV, Couttet P, Soond DR, van Dongen S, Grocock RJ, Das PP, Miska EA et al: Requirement of bic/microRNA-155 for normal immune function. Science 2007, 316(5824):608-611.

57. Mavrakis KJ, Wolfe AL, Oricchio E, Palomero T, de Keersmaecker K, McJunkin K, Zuber J, James T, Khan AA, Leslie CS et al: Genome-wide RNA-mediated interference screen identifies miR-19 targets in Notch-induced T-cell acute lymphoblastic leukaemia. Nat Cell Biol 2010, 12(4):372-379.

58. Nie K, Gomez M, Landgraf P, Garcia JF, Liu Y, Tan LH, Chadburn A, Tuschl T, Knowles DM, Tam W: MicroRNA-mediated down-regulation of PRDM1/Blimp-1 in Hodgkin/Reed-Sternberg cells: a potential pathogenetic lesion in Hodgkin lymphomas. Am J Pathol 2008, 173(1):242-252.

59. Santanam U, Zanesi N, Efanov A, Costinean S, Palamarchuk A, Hagan JP, Volinia S, Alder H, Rassenti L, Kipps T et al: Chronic lymphocytic leukemia modeled in mouse by targeted miR-29 expression. Proc Natl Acad Sci U S A 2010, 107(27):12210-12215.

60. Szafranska-Schwarzbach AE, Adai AT, Lee LS, Conwell DL, Andruss BF: Development of a miRNA-based diagnostic assay for pancreatic ductal adenocarcinoma. Expert Rev Mol Diagn 2007, 11(3):249-257.

61. Zhang Y, Li M, Wang H, Fisher WE, Lin PH, Yao Q, Chen C: Profiling of 95 microRNAs in pancreatic cancer cell lines and surgical specimens by real-time PCR analysis. World J Surg 2009, 33(4):698-709.

62. Ohgaki H: Genetic pathways to glioblastomas. Neuropathology 2005, 25(1):1-7.

63. Han L, Yue X, Zhou X, Lan FM, You G, Zhang W, Zhang KL, Zhang CZ, Cheng JQ, Yu SZ et al: MicroRNA-21 Expression is regulated by beta-catenin/STAT3 Pathway and Promotes Glioma Cell Invasion by Direct Targeting RECK. CNS Neurosci Ther 2012.

64. Papagiannakopoulos T, Shapiro A, Kosik KS: MicroRNA-21 targets a network of key tumor-suppressive pathways in glioblastoma cells. Cancer Res 2008, 68(19):8164-8172.

65. Quintavalle C, Garofalo M, Zanca C, Romano G, Iaboni M, del Basso De Caro M, Martinez-Montero JC, Incoronato M, Nuovo G, Croce CM et al: miR-221/222 overexpession in human glioblastoma increases invasiveness by targeting the protein phosphate PTPmu. Oncogene 2012, 31(7):858-868.

66. le Sage C, Nagel R, Egan DA, Schrier M, Mesman E, Mangiola A, Anile C, Maira G, Mercatelli N, Ciafre SA et al: Regulation of the p27(Kip1) tumor suppressor by miR-221 and miR-222 promotes cancer cell proliferation. EMBO J 2007, 26(15):3699-3708

67. Feng SY, Dong CG, Wu WK, Wang XJ, Qiao J, Shao JF: Lentiviral expression of anti-microRNAs targeting miR-27a inhibits proliferation and invasiveness of U87 glioma cells. Mol Med Report 2012.

68. Shi L, Cheng Z, Zhang J, Li R, Zhao P, Fu Z, You Y: hsa-mir-181a and hsa-mir-181b function as tumor suppressors in human glioma cells. Brain Res 2008, 1236:185-193.

69. Wu DG, Wang YY, Fan LG, Luo H, Han B, Sun LH, Wang XF, Zhang JX, Cao L, Wang XR et al: MicroRNA-7 regulates glioblastoma cell invasion via targeting focal adhesion kinase expression. Chin Med J (Engl) 2011, 124(17):2616-2621.

70. Sun L, Wu Z, Shao Y, Pu Y, Miu W, Yao J, Wu Y, Yang ZX: MicroRNA-34a Suppresses Cell Proliferation and Induces Apoptosis in U87 Glioma Stem Cells. Technol Cancer Res Treat 2012.

71. Godlewski J, Nowicki MO, Bronisz A, Williams S, Otsuki A, Nuovo G, Raychaudhury A, Newton HB, Chiocca EA, Lawler S: Targeting of the Bmi-1 oncogene/stem cell renewal factor by microRNA-128 inhibits glioma proliferation and self-renewal. Cancer Res 2008, 68(22):9125-9130.

72. Zhang Y, Chao T, Li R, Liu W, Chen Y, Yan X, Gong Y, Yin B, Qiang B, Zhao J et al: MicroRNA-128 inhibits glioma cells proliferation by targeting transcription factor E2F3a. J Mol Med (Berl) 2009, 87(1):43-51

73. Wang XF, Shi ZM, Wang XR, Cao L, Wang YY, Zhang JX, Yin Y, Luo H, Kang CS, Liu $\mathrm{N}$ et al: MiR-181d acts as a tumor suppressor in glioma by targeting K-ras and Bcl-2. J Cancer Res Clin Oncol 2012, 138(4):573-584.

74. Volpe A, Patard JJ: Prognostic factors in renal cell carcinoma. World J Urol 2010, 28(3):319-327.

75. Juan D, Alexe G, Antes T, Liu H, Madabhushi A, Delisi C, Ganesan S, Bhanot $\mathrm{G}$, Liou LS: Identification of a microRNA panel for clear-cell kidney cancer. Urology 2010, 75(4):835-841.

76. Catto JW, Alcaraz A, Bjartell AS, De Vere White R, Evans CP, Fussel S, Hamdy FC, Kallioniemi O, Mengual L, Schlomm T et al: MicroRNA in prostate, bladder, and kidney cancer: a systematic review. Eur Urol 2011, 59(5):671-681.

77. Pantuck AJ, Seligson DB, Klatte T, Yu H, Leppert JT, Moore L, O'Toole T, Gibbons J, Belldegrun AS, Figlin RA: Prognostic relevance of the mTOR pathway in renal cell carcinoma: implications for molecular patient selection for targeted therapy. Cancer 2007, 109(11):2257-2267.

78. Dromard M, Bompard G, Glondu-Lassis M, Puech C, Chalbos D, Freiss G: The putative tumor suppressor gene PTPN13/PTPL1 induces apoptosis through insulin receptor substrate-1 dephosphorylation. Cancer Res 2007, 67(14):6806-6813.
79. Felipe A, Vicente R, Villalonga N, Roura-Ferrer M, Martinez-Marmol R, Sole L, Ferreres JC, Condom E: Potassium channels: new targets in cancer therapy. Cancer Detect Prev 2006, 30(4):375-385.

80. Wong CF, Tellam RL: MicroRNA-26a targets the histone methyltransferase Enhancer of Zeste homolog 2 during myogenesis. J Biol Chem 2008, 283(15):9836-9843.

81. Tsang WP, Kwok TT: Epigallocatechin gallate up-regulation of miR-16 and induction of apoptosis in human cancer cells. J Nutr Biochem 2010, 21(2):140-146.

82. Kaddar T, Rouault JP, Chien WW, Chebel A, Gadoux M, Salles G, Ffrench M, Magaud JP: Two new miR-16 targets: caprin-1 and HMGA1, proteins implicated in cell proliferation. Biol Cell 2009, 101(9):511-524.

83. UK CR: Cancer incidence for common cancers. 2011.

84. Harris JR, Morrow M, Bonadonna G, Valadi H: Cancer of the breast. Philadelphia: Lippincott 1993.

85. Schecter RL, Woo A, Duong M, Batist G: In vivo and in vitro mechanisms of drug resistance in a rat mammary carcinoma model. Cancer Res 1991, 51(5):1434-1442.

86. Wright JA, Richer JK, Goodall GJ: microRNAs and EMT in mammary cells and breast cancer. J Mammary Gland Biol Neoplasia 2010, 15(2):213-223.

87. Greene SB, Herschkowitz JI, Rosen JM: Small players with big roles: microRNAs as targets to inhibit breast cancer progression. Curr Drug Targets 2010, 11(9):1059-1073.

88. Lu Y, Roy S, Nuovo G, Ramaswamy B, Miller T, Shapiro C, Jacob ST, Majumder S: Anti-microRNA-222 (anti-miR-222) and -181B suppress growth of tamoxifen-resistant xenografts in mouse by targeting TIMP3 protein and modulating mitogenic signal. J Biol Chem 2011, 286(49):42292-42302.

89. Miller TE, Ghoshal K, Ramaswamy B, Roy S, Datta J, Shapiro CL, Jacob S, Majumder S: MicroRNA-221/222 confers tamoxifen resistance in breast cancer by targeting p27Kip1. J Biol Chem 2008, 283(44):29897-29903.

90. Frankel LB, Christoffersen NR, Jacobsen A, Lindow M, Krogh A, Lund AH: Programmed cell death 4 (PDCD4) is an important functional target of the microRNA miR-21 in breast cancer cells. J Biol Chem 2008, 283(2):1026-1033.

91. Ma L, Teruya-Feldstein J, Weinberg RA: Tumour invasion and metastasis initiated by microRNA-10b in breast cancer. Nature 2007, 449(7163):682-688

92. Jiang S, Zhang HW, Lu MH, He XH, Li Y, Gu H, Liu MF, Wang ED: MicroRNA-155 functions as an OncomiR in breast cancer by targeting the suppressor of cytokine signaling 1 gene. Cancer Res 2010, 70(8):3119-3127.

93. Schmittgen TD: miR-31: a master regulator of metastasis? Future Oncol 2010, 6(1):17-20.

94. Korpal M, Lee ES, Hu G, Kang Y: The miR-200 family inhibits epithelial-mesenchymal transition and cancer cell migration by direct targeting of E-cadherin transcriptional repressors ZEB1 and ZEB2. J Biol Chem 2008, 283(22):14910-14914.

95. Howe EN, Cochrane DR, Richer JK: Targets of miR-200c mediate suppression of cell motility and anoikis resistance. Breast Cancer Res 2011, 13(2):R45.

96. Schickel R, Park SM, Murmann AE, Peter ME: miR-200c regulates induction of apoptosis through CD95 by targeting FAP-1. Mol Cell 2010, 38(6):908-915.

97. Ma L, Young J, Prabhala H, Pan E, Mestdagh P, Muth D, Teruya-Feldstein J, Reinhardt F, Onder TT, Valastyan S et al: miR-9, a MYC/MYCN-activated microRNA, regulates E-cadherin and cancer metastasis. Nat Cell Biol 2010, 12(3):247-256.

98. Christoffersen NR, Silahtaroglu A, Orom UA, Kauppinen S, Lund AH: miR-200b mediates post-transcriptional repression of ZFHX1B. RNA 2007, 13(8):1172-1178.

99. Hurteau GJ, Carlson JA, Spivack SD, Brock GJ: Overexpression of the microRNA hsa-miR-200c leads to reduced expression of transcription factor 8 and increased expression of E-cadherin. Cancer Res 2007, 67(17):7972-7976.

100. Gregory PA, Bert AG, Paterson EL, Barry SC, Tsykin A, Farshid G, Vadas MA, Khew-Goodall Y, Goodall GJ: The miR-200 family and miR-205 regulate epithelial to mesenchymal transition by targeting ZEB1 and SIP1. Nat Cell Biol 2008, 10(5):593-601.

101. Iorio MV, Casalini P, Tagliabue E, Menard S, Croce CM: MicroRNA profiling as a tool to understand prognosis, therapy response and resistance in breast cancer. Eur J Cancer 2008, 44(18):2753-2759.

102. Mattie MD, Benz CC, Bowers J, Sensinger K, Wong L, Scott GK, Fedele V, Ginzinger D, Getts R, Haqq C: Optimized high-throughput microRNA expression profiling provides novel biomarker assessment of clinical prostate and breast cancer biopsies. Mol Cancer 2006, 5:24.

103. Zhu W, Qin W, Atasoy U, Sauter ER: Circulating microRNAs in breast cancer and healthy subjects. BMC Res Notes 2009, 2:89.

104. Tavazoie SF, Alarcon C, Oskarsson T, Padua D, Wang Q, Bos PD, Gerald WL Massague J: Endogenous human microRNAs that suppress breast cancer metastasis. Nature 2008, 451(7175):147-152

105. Foekens JA, Sieuwerts AM, Smid M, Look MP, de Weerd V, Boersma AW, Klijn JG, Wiemer EA, Martens JW: Four miRNAs associated with aggressiveness of lymph node-negative, estrogen receptor-positive human breast cancer. Proc Natl Acad Sci U S A 2008, 105(35):13021-13026.

106. Zhao JJ, Lin J, Yang H, Kong W, He L, Ma X, Coppola D, Cheng JQ: MicroRNA-221/222 negatively regulates estrogen receptor alpha and is associated with tamoxifen resistance in breast cancer. J Biol Chem 2008, 283(45):31079-31086

107. Si ML, Zhu S, Wu H, Lu Z, Wu F, Mo YY: miR-21-mediated tumor growth. Oncogene 2007, 26(19):2799-2803. 
108. Saito Y, Liang G, Egger G, Friedman JM, Chuang JC, Coetzee GA, Jones PA: Specific activation of microRNA-127 with downregulation of the proto-oncogene BCL6 by chromatin-modifying drugs in human cancer cells. Cancer Cell 2006, 9(6):435-443.

109. Giraldez AJ, Cinalli RM, Glasner ME, Enright AJ, Thomson JM, Baskerville S, Hammond SM, Bartel DP, Schier AF: MicroRNAs regulate brain morphogenesis in zebrafish. Science 2005, 308(5723):833-838.

110. Brown BD, Venneri MA, Zingale A, Sergi Sergi L, Naldini L: Endogenous microRNA regulation suppresses transgene expression in hematopoietic lineages and enables stable gene transfer. Nat Med 2006, 12(5):585-591.

111. Brown BD, Gentner B, Cantore A, Colleoni S, Amendola M, Zingale A, Baccarini A, Lazzari G, Galli C, Naldini L: Endogenous microRNA can be broadly exploited to regulate transgene expression according to tissue, lineage and differentiation state. Nat Biotechnol 2007, 25(12):1457-1467.

112. Kato Y, Miyaki S, Yokoyama S, Omori S, Inoue A, Horiuchi M, Asahara H: Real-time functional imaging for monitoring miR-133 during myogenic differentiation. Int J Biochem Cell Biol 2009, 41(11):2225-2231.

113. Kato Y, Sawata SY, Inoue A: A lentiviral vector encoding two fluorescent proteins enables imaging of adenoviral infection via adenovirus-encoded miRNAs in single living cells. J Biochem 2010, 147(1):63-71.

114. Kim JK, Choi KJ, Lee M, Jo MH, Kim S: Molecular imaging of a cancer-targeting theragnostics probe using a nucleolin aptamer- and microRNA-221 molecular beacon-conjugated nanoparticle. Biomaterials 2012, 33(1):207-217.

115. Lee JY, Kim S, Hwang do W, Jeong JM, Chung JK, Lee MC, Lee DS: Development of a dual-luciferase reporter system for in vivo visualization of MicroRNA biogenesis and posttranscriptional regulation. J Nucl Med 2008, 49(2):285-294.

116. Ko MH, Kim S, Hwang do W, Ko HY, Kim YH, Lee DS: Bioimaging of the unbalanced expression of microRNA9 and microRNA9* during the neuronal differentiation of P19 cells. FEBS J 2008, 275(10):2605-2616.

117. Kim HJ, Kim YH, Lee DS, Chung JK, Kim S: In vivo imaging of functional targeting of miR-221 in papillary thyroid carcinoma. J Nucl Med 2008, 49(10):1686-1693.

118. Kim HJ, Chung JK, Hwang do W, Lee DS, Kim S: In vivo imaging of miR-221 biogenesis in papillary thyroid carcinoma. Mol Imaging Biol 2009, 11(2):71-78.

119. Takeshita F, Patrawala L, Osaki M, Takahashi RU, Yamamoto Y, Kosaka N, Kawamata M, Kelnar K, Bader AG, Brown D et al: Systemic delivery of synthetic microRNA-16 inhibits the growth of metastatic prostate tumors via downregulation of multiple cell-cycle genes. Mol Ther 2010, 18(1):181-187.

120. Ma C, Yeung ES, Qi S, Han R: Highly sensitive detection of microRNA by chemiluminescence based on enzymatic polymerization. Anal Bioanal Chem 2011, 402(6):2217-2220.

121. Ponomarev ED, Veremeyko T, Barteneva NS: Visualization and quantitation of the expression of microRNAs and their target genes in neuroblastoma single cells using imaging cytometry. BMC Res Notes 2011, 4:517.

122. Nuovo G, Lee EJ, Lawler S, Godlewski J, Schmittgen T: In situ detection of mature microRNAs by labeled extension on ultramer templates. Biotechniques 2009, 46(2):115-126.

123. Roy S, Soh JH, Gao Z: A microfluidic-assisted microarray for ultrasensitive detection of miRNA under an optical microscope. Lab Chip 2011, 11(11):1886-1894.

124. Jo MH, Ali BA, Al-Khedhairy AA, Lee CH, Kim B, Haam S, Huh YM, Ko HY, Kim S: A reverse complementary multimodal imaging system to visualize microRNA9-involved neurogenesis using peptide targeting transferrin receptor-conjugated magnetic fluorescence nanoparticles. Biomaterials 2012, 33(27):6456-6467.

125. Yang W, Qin W, Hu Z, Suo Y, Zhao R, Ma X, Ma W, Wang T, Liang J, Tian J et al: Comparison of Cerenkov Luminescence Imaging (CLI) and gamma camera imaging for visualization of let-7 expression in lung adenocarcinoma A549 Cells. Nucl Med Biol 2012

126. Lussier YA, Xing HR, Salama JK, Khodarev NN, Huang Y, Zhang Q, Khan SA, Yang $X$, Hasselle MD, Darga TE et al: MicroRNA expression characterizes oligometastasis(es). PLoS One 2011, 6(12):e28650.

127. Akinc A, Zumbuehl A, Goldberg M, Leshchiner ES, Busini V, Hossain N, Bacallado SA, Nguyen DN, Fuller J, Alvarez R et al: A combinatorial library of lipid-like materials for delivery of RNAi therapeutics. Nat Biotechnol 2008, 26(5):561-569.

128. Krutzfeldt J, Kuwajima S, Braich R, Rajeev KG, Pena J, Tuschl T, Manoharan M, Stoffel M: Specificity, duplex degradation and subcellular localization of antagomirs. Nucleic Acids Res 2007, 35(9):2885-2892.

129. van Solingen C, Seghers L, Bijkerk R, Duijs JM, Roeten MK, van Oeveren-Rietdijk AM, Baelde HJ, Monge M, Vos JB, de Boer HC et al: Antagomir-mediated silencing of endothelial cell specific microRNA-126 impairs ischemia-induced angiogenesis. J Cell Mol Med 2009, 13(8A):1577-1585.

130. Paulmurugan R, Sekar NM, Sekar TV: Biodegradable Polymer Nanocarriers for Therapeutic Antisense microRNA Delivery in Living Animals. SPIE 2012, 8232 .

131. Boutla A, Delidakis C, Tabler M: Developmental defects by antisense-mediated inactivation of micro-RNAs 2 and 13 in Drosophila and the identification of putative target genes. Nucleic Acids Res 2003, 31(17):4973-4980.

132. Davis S, Lollo B, Freier S, Esau C: Improved targeting of miRNA with antisense oligonucleotides. Nucleic Acids Res 2006, 34(8):2294-2304.
133. Chiu YL, Rana TM: siRNA function in RNAi: a chemical modification analysis. RNA 2003, 9(9):1034-1048

134. Czauderna F, Fechtner M, Dames S, Aygun H, Klippel A, Pronk GJ, Giese K, Kaufmann J: Structural variations and stabilising modifications of synthetic siRNAs in mammalian cells. Nucleic Acids Res 2003, 31(11):2705-2716.

135. Prakash TP, Allerson CR, Dande P, Vickers TA, Sioufi N, Jarres R, Baker BF, Swayze EE, Griffey RH, Bhat B: Positional effect of chemical modifications on short interference RNA activity in mammalian cells. J Med Chem 2005, 48(13):4247-4253.

136. Uprichard SL, Boyd B, Althage A, Chisari FV: Clearance of hepatitis B virus from the liver of transgenic mice by short hairpin RNAs. Proc Natl Acad Sci U S A 2005, 102(3):773-778.

137. Xia H, Mao Q, Paulson HL, Davidson BL: siRNA-mediated gene silencing in vitro and in vivo. Nat Biotechnol 2002, 20(10):1006-1010.

138. Ebert MS, Neilson JR, Sharp PA: MicroRNA sponges: competitive inhibitors of small RNAs in mammalian cells. Nat Methods 2007, 4(9):721-726.

139. Ebert MS, Sharp PA: MicroRNA sponges: progress and possibilities. RNA 2010, 16(11):2043-2050.

140. Kluiver J, Gibcus JH, Hettinga C, Adema A, Richter MK, Halsema N, Slezak-Prochazka I, Ding Y, Kroesen BJ, van den Berg A: Rapid generation of microRNA sponges for microRNA inhibition. PLoS One 2012, 7(1):e29275.

141. Sato F, Tsuchiya S, Meltzer SJ, Shimizu K: MicroRNAs and epigenetics. FEBS J 2011, 278(10):1598-1609.

142. Kutay H, Bai S, Datta J, Motiwala T, Pogribny I, Frankel W, Jacob ST, Ghoshal $\mathrm{K}$ : Downregulation of miR-122 in the rodent and human hepatocellular carcinomas. J Cell Biochem 2006, 99(3):671-678.

143. Su H, Yang JR, Xu T, Huang J, Xu L, Yuan Y, Zhuang SM: MicroRNA-101, down-regulated in hepatocellular carcinoma, promotes apoptosis and suppresses tumorigenicity. Cancer Res 2009, 69(3):1135-1142.

144. Zheng B, Liang L, Huang S, Zha R, Liu L, Jia D, Tian Q, Wang Q, Wang C, Long Z et al: MicroRNA-409 suppresses tumour cell invasion and metastasis by directly targeting radixin in gastric cancers. Oncogene 2011.

145. Zhai Q, Zhou L, Zhao C, Wan J, Yu Z, Guo X, Qin J, Chen J, Lu R: Identification of miR-508-3p and miR-509-3p that are associated with cell invasion and migration and involved in the apoptosis of renal cell carcinoma. Biochem Biophys Res Commun 2012, 419(4):621-626.

146. Yan D, Dong Xda E, Chen X, Wang L, Lu C, Wang J, Qu J, Tu L: MicroRNA-1/206 targets c-Met and inhibits rhabdomyosarcoma development. J Biol Chem 2009, 284(43):29596-29604.

147. Rota R, Ciarapica R, Giordano A, Miele L, Locatelli F: MicroRNAs in rhabdomyosarcoma: pathogenetic implications and translational potentiality. Mol Cancer 2011, 10:120.

148. Liao YL, Hu LY, Tsai KW, Wu CW, Chan WC, Li SC, Lai CH, Ho MR, Fang WL, Huang KH et al: Transcriptional regulation of miR-196b by ETS2 in gastric cancer cells. Carcinogenesis 2012, 33(4):760-769.

149. Noguchi S, Mori T, Otsuka Y, Yamada N, Yasui Y, Iwasaki J, Kumazaki M, Maruo K, Akao Y: Anti-oncogenic microRNA-203 induces senescence by targeting E2F3 protein in human melanoma cells. J Biol Chem 2012, 287(15):11769-11777.

150. Xu Y, Brenn T, Brown ER, Doherty V, Melton DW: Differential expression of microRNAs during melanoma progression: miR-200c, miR-205 and miR-211 are downregulated in melanoma and act as tumour suppressors. $\mathrm{Br} J$ Cancer 2012, 106(3):553-561.

151. Song G, Zeng H, Li J, Xiao L, He Y, Tang Y, Li Y: miR-199a regulates the tumor suppressor mitogen-activated protein kinase kinase kinase 11 in gastric cancer. Biol Pharm Bull 2010, 33(11):1822-1827.

152. Zhao X, Dou W, He L, Liang S, Tie J, Liu C, Li T, Lu Y, Mo P, Shi Y et al: MicroRNA-7 functions as an anti-metastatic microRNA in gastric cancer by targeting insulin-like growth factor-1 receptor. Oncogene 2012.

153. Duex JE, Comeau L, Sorkin A, Purow B, Kefas B: Usp18 regulates epidermal growth factor (EGF) receptor expression and cancer cell survival via microRNA-7. I Biol Chem 2011, 286(28):25377-25386.

154. Landais S, Landry S, Legault P, Rassart E: Oncogenic potential of the miR-106-363 cluster and its implication in human T-cell leukemia. Cancer Res 2007, 67(12):5699-5707.

155. Hamada S, Satoh K, Fujibuchi W, Hirota M, Kanno A, Unno J, Masamune A, Kikuta K, Kume K, Shimosegawa T: MiR-126 acts as a tumor suppressor in pancreatic cancer cells via the regulation of ADAM9. Mol Cancer Res 2012, 10(1):3-10.

156. Bhatti I, Lee A, James V, Hall RI, Lund JN, Tufarelli C, Lobo DN, Larvin M: Knockdown of microRNA-21 inhibits proliferation and increases cell death by targeting programmed cell death 4 (PDCD4) in pancreatic ductal adenocarcinoma. J Gastrointest Surg 2011, 15(1):199-208.

157. Chen L, Jiang M, Yuan W, Tang H: miR-17-5p as a novel prognostic marker for hepatocellular carcinoma. I Invest Surg 2012, 25(3):156-161.

158. Xu Y, Fang F, Zhang J, Josson S, St Clair WH, St Clair DK: miR-17* suppresses tumorigenicity of prostate cancer by inhibiting mitochondrial antioxidant enzymes. PLoS One 2010, 5(12):e14356

159. Moriarty $\mathrm{CH}$, Pursell B, Mercurio AM: miR-10b targets Tiam1: implications for Rac activation and carcinoma migration. J Biol Chem 2010, 285(27):20541-20546.

160. Hatziapostolou M, Polytarchou C, Aggelidou E, Drakaki A, Poultsides GA, Jaeger SA, Ogata H, Karin M, Struhl K, Hadzopoulou-Cladaras M et al: An HNF4alpha-miRNA inflammatory feedback circuit regulates hepatocellular oncogenesis. Cell 2011, 147(6):1233-1247. 
161. Garofalo M, Di Leva G, Romano G, Nuovo G, Suh SS, Ngankeu A, Taccioli C, Pichiorri F, Alder H, Secchiero P et al: miR-221\&222 regulate TRAIL resistance and enhance tumorigenicity through PTEN and TIMP3 downregulation. Cancer Cell 2009, 16(6):498-509.

162. Acunzo M, Visone R, Romano G, Veronese A, Lovat F, Palmieri D, Bottoni A, Garofalo M, Gasparini P, Condorelli G et al: miR-130a targets MET and induces TRAIL-sensitivity in NSCLC by downregulating miR-221 and 222. Oncogene 2012, 31(5):634-642.

163. Bandi N, Vassella E: miR-34a and miR-15a/16 are co-regulated in non-small cell lung cancer and control cell cycle progression in a synergistic and Rb-dependent manner. Mol Cancer 2011, 10:55.

164. Young LE, Moore AE, Sokol L, Meisner-Kober N, Dixon DA: The mRNA stability factor HuR inhibits microRNA-16 targeting of COX-2. Mol Cancer Res 2011, 10(1):167-180.

165. Valeri N, Gasparini P, Fabbri M, Braconi C, Veronese A, Lovat F, Adair B, Vannini I, Fanini F, Bottoni A et al: Modulation of mismatch repair and genomic stability by miR-155. Proc Natl Acad Sci U S A 2010, 107(15):6982-6987.

166. Yamakuchi $M$, Ferlito $M$, Lowenstein CJ: miR-34a repression of SIRT1 regulates apoptosis. Proc Natl Acad Sci U S A 2008, 105(36):13421-13426.

167. Slaby O, Svoboda M, Michalek J, Vyzula R: MicroRNAs in colorectal cancer: translation of molecular biology into clinical application. Mol Cancer 2009, $8: 102$.

168. Eis PS, Tam W, Sun L, Chadburn A, Li Z, Gomez MF, Lund E, Dahlberg JE: Accumulation of miR-155 and BIC RNA in human B cell lymphomas. Proc Natl Acad Sci U S A 2005, 102(10):3627-3632.

169. Wang M, Tan LP, Dijkstra MK, van Lom K, Robertus JL, Harms G, Blokzijl T, Kooistra K, van T'veer M B, Rosati S et al: miRNA analysis in B-cell chronic lymphocytic leukaemia: proliferation centres characterized by low miR-150 and high BIC/miR-155 expression. J Pathol 2008, 215(1):13-20.

170. Wang W, Corrigan-Cummins M, Hudson J, Maric I, Simakova O, Neelapu SS, Kwak LW, Janik JE, Gause B, Jaffe ES et al: MicroRNA profiling of follicular lymphoma identifies microRNAs related to cell proliferation and tumor response. Haematologica 2012, 97(4):586-594.

171. Szafranska AE, Davison TS, John J, Cannon T, Sipos B, Maghnouj A, Labourier E, Hahn SA: MicroRNA expression alterations are linked to tumorigenesis and non-neoplastic processes in pancreatic ductal adenocarcinoma. Oncogene 2007, 26(30):4442-4452.

172. Steele CW, Oien KA, McKay CJ, Jamieson NB: Clinical potential of microRNAs in pancreatic ductal adenocarcinoma. Pancreas 2011, 40(8):1165-1171.

173. Stinson S, Lackner MR, Adai AT, Yu N, Kim HJ, O'Brien C, Spoerke J, Jhunihunwala S, Boyd Z, Januario $T$ et al: miR-221/222 targeting of trichorhinophalangeal 1 (TRPS1) promotes epithelial-to-mesenchymal transition in breast cancer. Sci Signal, 2011;4(186):pt5.

174. Zhu S, Si ML, Wu H, Mo YY: MicroRNA-21 targets the tumor suppressor gene tropomyosin 1 (TPM1). J Biol Chem 2007, 282(19):14328-14336.

175. Chen PS, Su JL, Cha ST, Tarn WY, Wang MY, Hsu HC, Lin MT, Chu CY, Hua $\mathrm{KT}$, Chen CN et al: miR-107 promotes tumor progression by targeting the let-7 microRNA in mice and humans. J Clin Invest 2011, 121(9):3442-3455.

176. Li H, Bian C, Liao L, Li J, Zhao RC: miR-17-5p promotes human breast cancer cell migration and invasion through suppression of HBP1. Breast Cancer Res Treat 2010, 126(3):565-575.

177. Wang J, Hua HJ: Role of miR-155 in breast cancer. Front Biosci 2012, 17:2350-2355.

178. Kong W, He L, Coppola M, Guo J, Esposito NN, Coppola D, Cheng JQ: MicroRNA-155 regulates cell survival, growth, and chemosensitivity by targeting FOXO3a in breast cancer. J Biol Chem 2010, 285(23):17869-17879. 